\title{
Review Article \\ Overview of Platelet Physiology: Its Hemostatic and Nonhemostatic Role in Disease Pathogenesis
}

\author{
Kakali Ghoshal and Maitree Bhattacharyya \\ Department of Biochemistry, University of Calcutta, 35 Ballygunge Circular Road, Kolkata 700019, India \\ Correspondence should be addressed to Maitree Bhattacharyya; bmaitree@gmail.com
}

Received 31 August 2013; Accepted 10 November 2013; Published 3 March 2014

Academic Editors: E. J. Benz, L. Olcay, and M. de F. Sonati

Copyright ( $) 2014$ K. Ghoshal and M. Bhattacharyya. This is an open access article distributed under the Creative Commons Attribution License, which permits unrestricted use, distribution, and reproduction in any medium, provided the original work is properly cited.

\begin{abstract}
Platelets are small anucleate cell fragments that circulate in blood playing crucial role in managing vascular integrity and regulating hemostasis. Platelets are also involved in the fundamental biological process of chronic inflammation associated with disease pathology. Platelet indices like mean platelets volume (MPV), platelets distributed width (PDW), and platelet crit (PCT) are useful as cheap noninvasive biomarkers for assessing the diseased states. Dynamic platelets bear distinct morphology, where $\alpha$ and dense granule are actively involved in secretion of molecules like GPIIb , IIIa, fibrinogen, vWf, catecholamines, serotonin, calcium, ATP, ADP, and so forth, which are involved in aggregation. Differential expressions of surface receptors like CD36, CD41, CD61 and so forth have also been quantitated in several diseases. Platelet clinical research faces challenges due to the vulnerable nature of platelet structure functions and lack of accurate assay techniques. But recent advancement in flow cytometry inputs huge progress in the field of platelets study. Platelets activation and dysfunction have been implicated in diabetes, renal diseases, tumorigenesis, Alzheimer's, and CVD. In conclusion, this paper elucidates that platelets are not that innocent as they keep showing and thus numerous novel platelet biomarkers are upcoming very soon in the field of clinical research which can be important for predicting and diagnosing disease state.
\end{abstract}

\section{Introduction}

Platelets were discovered by Giulio Bizzozero in 1882 [1], but for many decades the dynamic and multifunctional nature of platelets remained a field of interest only for biologists. Anucleate, discoid platelets are the smallest blood particles which unveil their dynamicity through their morphology. Primarily they are associated with hemostasis, which is to initiate blood coagulation. Although very dynamic, they usually prefer to remain in inactive state and get activated only when a blood vessel is damaged. But hemostasis or blood coagulation is not the sole function of platelets; rather it is employed in several multifunctional attributes monitoring the homeostasis of the body. Its high sensitivity to different disease states eventually assigned it to be one of the most accessible markers. While keeping interactions with leukocytes and endothelial cells, it restores its behaviour as an important inflammatory marker [2]. Platelet reactivity for different disease pathogenesis is widely dependent upon some biologically active markers like CD36, CD41, CD42a, CD42b, and CD61. These include some active surface receptors and platelet secretory products. Platelet tends to alter the expression and signaling of these markers in different disease diagnosis and prognosis, providing a huge field to explore disease progression.

Primarily, platelet activity is associated with the initiation of coagulation cascades. Damage in blood vessel makes the subendothelial surface the primary target site of platelet action, where it establishes the hemostasis. Various proaggregatory stimuli also known as platelet agonists promote the action of platelet adhesion to the subendothelial surfaces. During this process, platelet changes its shape, releases its granule contents, and gradually forms aggregates by adhering with each other [3]. Thus its primary activity remains associated with minimizing blood loss. However, as discussed earlier platelets are not only confined in regulating hemostasis and thrombosis, but they also play many pivotal roles in disease pathophysiology. Platelet interaction and cardiovascular disease progression remain an unsolved riddle for many years 


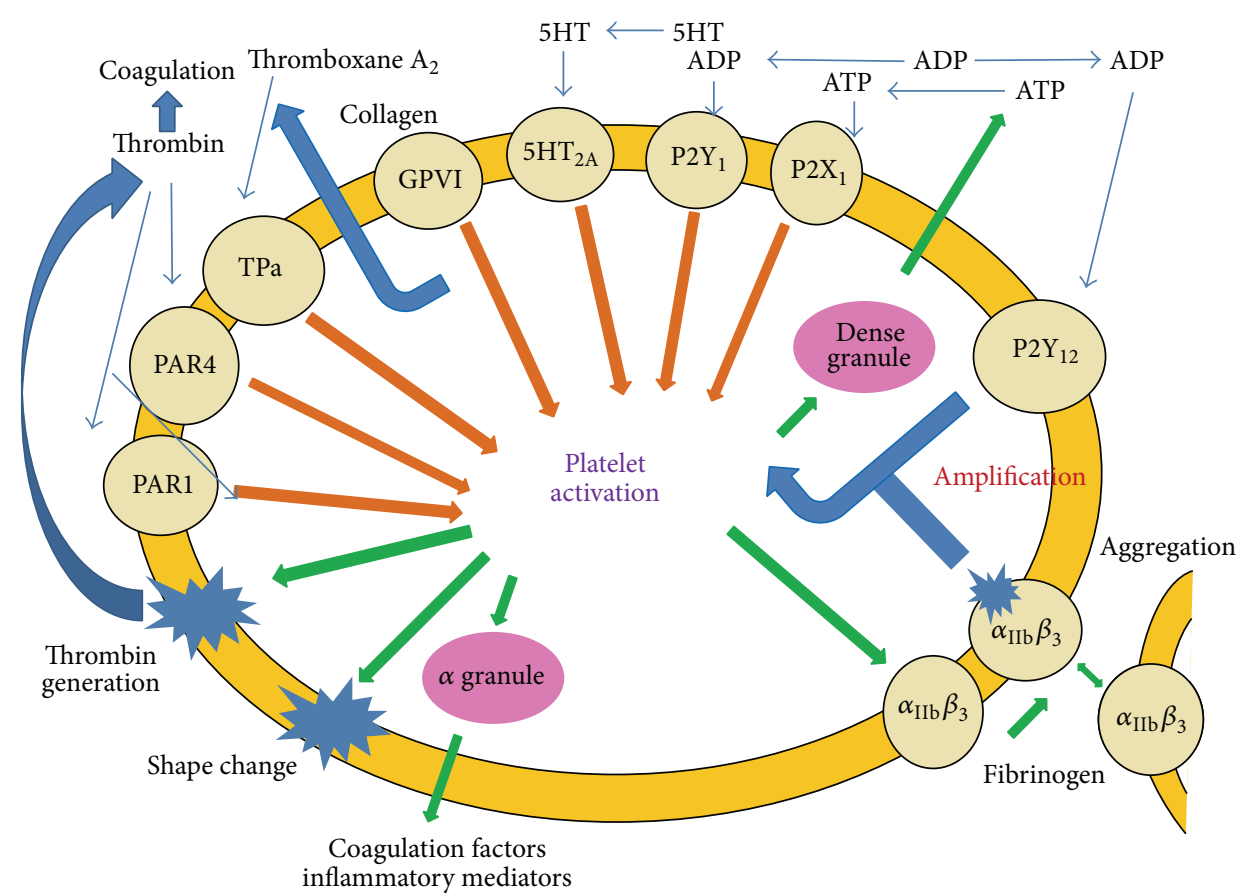

FIGURE 1: Platelet-activation mechanisms and role of the $\mathrm{P} 2 \mathrm{Y}_{12}$ receptor. Platelet activation leads to dense-granule secretion of ADP, which activates $\mathrm{P} 2 \mathrm{Y}_{12}$, inducing amplification of aggregation, procoagulant, and proinflammatory responses (adapted from Storey, 2008 [7]).

[4]. Platelet hyperaggregation among the diabetic patients with CVD remains another striking area to explore. Platelet hyperactivity in various diseases provokes adverse effects in some cases, especially in coronary artery disease where hyperaggregation obstructs blood circulation.

Expression of platelet markers can be well studied by ELISA or Western blot. However, till date flow cytometry is the best standardized method to study platelet function $[5,6]$. In this paper, we have tried to elucidate various aspects of platelets structure and function and their potential role in disease pathophysiology.

\section{Versatility of Platelets: Its Structural and Functional Aspects}

2.1. Ultrastructure. Platelet ultrastructure reveals its behavioural peculiarities. Megakaryocytes of the bone marrow are site of platelet formation. Diameter of a mature platelet is 2-3 $\mu \mathrm{m}$, which usually remains alive for 5-9 days. Approximately $2 / 3$ of the platelets circulate in the blood and $1 / 3$ is stored in the spleen. The normal platelet count is (150$400) \times 10^{3}$ per microliter of blood. Each megakaryocyte can produce 5000-10000 platelets. An average healthy adult can produce $10^{11}$ platelets per day; old platelets are destroyed by phagocytosis in the spleen and liver (Kupffer cells).

Platelets are unique in their structural assembly, though they are anucleate but have distinct mitochondria. Platelet plasma membrane, composed of phospholipid bilayer, is the site of expression of various surface receptors and lipid rafts which helps in signalling and intracellular trafficking. These markers include CD36, CD63, CD9, GPCR, IIbIIIa, and GLUT-3. These surface receptors also trigger the release of $\alpha$ granules which play a role in multiple functions, namely, coagulation, inflammation, atherosclerosis, antimicrobial host defense, angiogenesis, wound repair, and tumorigenesis [9]. Among these surface receptors, GPCR has been reported to play crucial role in ADP secretion from dense granules which is its major secretory product [10]. Asymmetrically arranged phospholipids (e.g., phosphatidylserine and phosphatidylinositol) present in the inner layer of the plasma membrane maintain the stability of its surface during nonprocoagulant state. During activation (Figure 1) platelet surface gradually exposes aminophospholipids by ATP-dependent floppases and scramblases to initiate coagulation cascades [11]. The open canalicular system (OCS) is the "tunnel" system present throughout the platelet cell and remains connected with the plasma membrane [12]. The major role of OCS is to give entry of external elements into the platelets as well as to release its granule contents to the exterior. Other than being a major storage site for plasma membrane glycoproteins, it facilitates the formation of filopodia during platelet activation [13]. Dense tubular system of platelets is a closed-channel network of residual endoplasmic reticulum and primarily involved in calcium sequestration with the help of cascades of reactions involving the activation of $\mathrm{G}$ protein-coupled receptor PAR-1 [14, 15]. The highly specialized cytoskeleton of platelets maintains its discoid structures as well as protects the cell from getting sheared in bloodstream. It has three major components: (1) the spectrinbased membrane skeleton, (2) the actin cytoskeleton, and (3) the marginal microtubule coil. 
Platelets have two major storage granules, namely, $\alpha$ and dense granules, whose function is to store biologically active molecules precisely involved in initiation of coagulation and recruiting other cells during inflammation [16]. The more prevalent $\alpha$ granule contains proteins (e.g., GPIIbIIIa, fibrinogen, and vWf) which initiate the coagulation cascades. Numerous membrane proteins essential to platelet function are also packaged into $\alpha$ granule which includes GPIIbIIIa, $\mathrm{P}$-selectin (CD62P), and CD36. $\alpha$ granules also have the bulk of cellular P-selectin in their membrane. P-selectin via Pselectin glycoprotein ligand (PSGL1) has been reported to recruit neutrophils $[17,18]$. Dense granules store a variety of hemostatically active molecules which are secreted during platelet activation; these include catecholamines, serotonin, calcium, adenosine $5^{\prime}$-diphosphate (ADP), and adenosine $5^{\prime}$ triphosphate (ATP). ADP is a weak platelet agonist, triggering platelet shape change, granule release, and aggregation [19].

2.2. Platelet Receptors. Platelet surface receptors have been always a field of interest among scientists for many years and platelets also can exert their granule contents during disease prognosis. A list of platelet receptors, also known as platelet agonists, have been summarized in (Table 1) according to their activity [20].

\subsection{Platelet Endothelium Interaction, Hemostasis, and Platelet} Aggregation. Platelets are completely different from endothelial cells and can interact in multiple ways when exposed to endothelial surface (Table 2). These interactions can be of cross talk over a distance also known as paracrine signaling via transient interactions or through receptor mediated cellcell adhesion. Platelets are also able to release or transfer many substances as discussed earlier that also interact with endothelial cell [21]. Although platelets and endothelial cells are different in many ways, they do share some common features, like both cell types are derived from a common bone marrow derived progenitor cell. Some of their transcriptional networks and gene expression programs are also similar like GATA-2, vWf, multimerin, and P-selectin. Both of them store their bioactive materials in their cytoplasmic granules. From an evolutionary approach, endothelium can be considered as sedentary in its way where platelets and megakaryocytes circulate in bloodstream [22].

Endothelial cells with the help of COX-1, COX-2, and prostacyclin synthase can convert arachidonic acid into prostacyclin, which in turn inhibits platelet function by the elevation of intracellular cyclic AMP levels [23].

An injury in the vessel wall activates platelets to initiate coagulation, which is also known as hemostasis. Dynamic platelets readily get activated/inhibited by several endogenous and exogenous stimuli. They initiate primary hemostasis by adhering themselves to the damaged vessel wall. GPIbV-IX and GPIa-IIa receptors and subendothelial compounds like vWf and collagen interact with each other to mediate this procedure (Figure 6). Binding of ligands to the GP receptors changes platelet shape as well as triggers the release of its granule contents, which ultimately leads to the formation of aggregates which are also known as "platelet plugs" or "white thrombi" (Figure 5).
Platelet starts to change its shape by the formation of pseudopods when intracellular $\mathrm{Ca}^{2+}$ concentration exceeds a specific threshold. During shape change, platelet fibrinogen receptors (GPIIb/IIIa) are exposed and activated, and platelet-platelet aggregation is initiated. This is also known as primary aggregation which is reversible. However, resting platelets are not able to bind fibrinogen. Arachidonic acid thromboxane pathway is an important platelet activation pathway (Figure 4). Aspirin, also known as acetylsalicylic acid, a drug widely used in CVD, inhibits platelet aggregation through irreversible acetylation and inactivation of COX, resulting in blockage of $\mathrm{TxA}_{2}$ production [24, 25]. Mature normal human platelets express only COX-1, as the anucleate platelet cannot synthesize enzyme de novo. As a result the effect of aspirin on them is permanent and cumulative. Thus, the cardioprotective effect of aspirin is exerted through the irreversible and permanent impairment of thromboxane $\mathrm{A}_{2}$ dependent platelet function, which reduces the development of acute arterial thrombosis [26].

ADP is another important platelet activator. $\mathrm{P}_{2} \mathrm{Y}_{12}$, an ADP specific receptor, is present on the platelet membrane and is coupled to inhibitory G-proteins and mediates ADPinduced release of $\mathrm{Ca}^{2+}$, inhibiting adenylate cyclase and activating the GPIIb/IIIa receptor which leads to platelet aggregation. The thienopyridines, ticlopidine, and clopidogrel inhibit platelet activation via blockage of the $\mathrm{P} 2 \mathrm{Y}_{12}$ receptor [27]. Thromboxane $A_{2}, A D P$, and other substances such as serotonin, released from the activated platelet, provide important positive feedback and strengthen the platelet-rich clot initiating secondary aggregation which is irreversible (Figure 3) [28].

Platelet response is amplified via substances released by platelet granules which recruit other platelets and blood cells. The platelet plug initially formed in primary hemostasis is relatively unstable. Coagulation cascade and formation of thrombin and fibrin prolong secondary hemostasis. During platelet activation, platelet membrane phospholipids become negatively charged, which facilitates coagulation activation (e.g., FV, FVIIIa, FIXa, and FX). Binding of the prothrombinase complex (FXa, $\mathrm{FVa}, \mathrm{Ca}^{2+}$, and prothrombin) to the platelet membrane occurs in this step. Further platelet activation is initiated by the formation of thrombin. These cascades lead to the formation of "red thrombus" strengthening the blood clot [29].

Intact vascular endothelium releases two major antiaggregants, prostacyclin $\left(\mathrm{PGI}_{2}\right)$ and nitric oxide $(\mathrm{NO})$, which prevent the formation of thrombus inside the blood vessel [31].

2.4. Platelet Function Assay. Platelets are dynamic blood particles which can interact with each other as well as with leukocyte and endothelial cells. Previously, platelet function was assessed using light transmission aggregometer [32] whose primary function was to measure the increase in light transmission through a platelet suspension when platelets were aggregated by an agonist. It has some major drawbacks. First of all, the result obtained may be affected by many variables. Secondly, the accuracy and the reproducibility of 
TABLE 1: Platelet receptors in different activation stages (adapted from Kauskot and Hoylaerts, 2012 [20]).

(a) Platelet receptors in recruitment, adhesion, and aggregation

\begin{tabular}{|c|c|c|c|c|}
\hline Receptors & Present in & Family & Ligands & Comments \\
\hline \multicolumn{5}{|c|}{ Initiation of platelet recruitment } \\
\hline GPIb-IX-V complex & Platelet surface & Leucine-rich repeat family & $\begin{array}{l}\text { vWf, thrombin, FXI, FXII, } \\
\text { P-selectin, HK, Mac-1, TSP-1 }\end{array}$ & $\begin{array}{l}\text { Bernard-Soulier } \\
\text { syndrome }\end{array}$ \\
\hline \multicolumn{5}{|c|}{ Platelet adhesion and aggregation } \\
\hline GPVI & Platelet surface & Ig superfamily & Collagen, laminin & \\
\hline$\alpha_{2} \beta_{1}$ & $\begin{array}{l}\text { Platelet plasma } \\
\text { membrane }\end{array}$ & Integrins & Collagen & \\
\hline$\alpha_{5} \beta_{1}$ & $”$ & ” & Fibronectin & \\
\hline$\alpha_{6} \beta_{1}$ & $”$ & ” & Laminin & \\
\hline$\alpha \mathrm{V} \beta_{3}$ & ” & ” & $\begin{array}{l}\text { Vitronectin, fibrinogen, vWf, } \\
\text { osteopontin }\end{array}$ & \\
\hline$\alpha_{\mathrm{IIb}} \beta_{3}$ & $"$ & ” & $\begin{array}{l}\text { Fibrinogen, fibrin, vWf, TSP-1, } \\
\text { fibronectin, vitronectin }\end{array}$ & $\begin{array}{l}\text { Glanzmann } \\
\text { thrombasthenia }\end{array}$ \\
\hline CD148 & Platelet surface & $\begin{array}{l}\text { Tyrosine phosphatase } \\
\text { receptor }\end{array}$ & Unknown & Regulation of GPVI \\
\hline CLEC-2 & $”$ & C-type lectin receptor & Podoplanin (platelets? CLEC-2?) & \\
\hline
\end{tabular}

(b) Platelet receptors in the amplification phase

\begin{tabular}{|c|c|c|c|c|}
\hline Receptors & Present in & Family & Ligands & Comments \\
\hline $\mathrm{P} 2 \mathrm{Y}_{1}$ & $\begin{array}{l}\text { Platelet plasma } \\
\text { membrane }\end{array}$ & $\begin{array}{l}\text { G protein-coupled } \\
\text { receptors }\end{array}$ & $\mathrm{ADP}$ & \\
\hline $\mathrm{P} 2 \mathrm{Y}_{12}$ & $”$ & $”$ & $”$ & \\
\hline PAR1 & $"$ & $"$ & Thrombin & High affinity \\
\hline PAR4 & $"$ & $"$ & $"$ & Low affinity \\
\hline tPA & $"$ & $"$ & Thromboxane & \\
\hline PAF receptors & $”$ & $”$ & $\begin{array}{l}\text { 1-O-alkyl-2-acetyl-sn-glycero-3- } \\
\text { phosphocholine }\end{array}$ & $\begin{array}{l}\text { PAF: platelet } \\
\text { activating factor }\end{array}$ \\
\hline $\mathrm{PGE}_{2}$ receptor $\left(\mathrm{EP}_{3}\right)$ & $"$ & ” & $\mathrm{PGE}_{2}$ & \\
\hline Lysophosphatidic acid receptor & $"$ & $"$ & Lysophosphatidic acid & \\
\hline Chemokine receptors & $”$ & $"$ & Chemokines & \\
\hline Vla vasopressin receptor & $"$ & $"$ & Vasopressin & \\
\hline A2a adenosine receptor & $"$ & $"$ & Adenosine & \\
\hline b2 adrenergic receptor & $"$ & $"$ & Epinephrine & \\
\hline Serotonin receptor & $”$ & $"$ & Serotonin (5-hydroxytryptamin) & \\
\hline Dopamine receptor & $"$ & $"$ & Dopamine & \\
\hline $\mathrm{P}_{2} \mathrm{X}_{1}$ & $"$ & Ion channel & ATP & \\
\hline c-Mp1 & $"$ & $\begin{array}{l}\text { Tyrosine kinase } \\
\text { receptor }\end{array}$ & TPO & \\
\hline Insulin receptor & $”$ & $"$ & Insulin & \\
\hline PDGF receptor & $"$ & $"$ & PDGF & \\
\hline Leptin receptor & $"$ & Cytokine & Leptin & \\
\hline
\end{tabular}

(c) Platelet receptors in the stabilization phase and in the negative regulation of platelet activation

\begin{tabular}{lcccc}
\hline Receptors & Present in & Family & Ligands & Comments \\
\hline & & Stabilization & \\
Eph receptor & Platelet plasma membrane & Tyrosine kinase receptor & Ephrin \\
Axl/Tyro3/Mer & $\cdots$ & $\cdots$ & Gas-6 \\
\hline
\end{tabular}


(c) Continued.

\begin{tabular}{|c|c|c|c|c|}
\hline Receptors & Present in & Family & Ligands & Comments \\
\hline P-selectin & $\begin{array}{c}\text { Platelet } \\
\alpha \text { granule; comes in plasma } \\
\text { membrane upon activation }\end{array}$ & $\begin{array}{l}\text { C-type lectin receptor } \\
\text { family }\end{array}$ & PSGL-1, GPIb, TF & $\begin{array}{c}\text { Soluble } \\
\text { P-selectin: biomarker }\end{array}$ \\
\hline TSSC6 & Platelet plasma membrane & Tetraspanins & - & \\
\hline CD151 & ” & $"$ & - & \\
\hline CD36 & $”$ & Class B scavenger receptor & $\begin{array}{l}\text { TSP1, oxLDL, VLDL, } \\
\text { oxPL, collagen type V }\end{array}$ & Many functions \\
\hline TLT-1 & $"$ & Ig superfamily & Fibrinogen? & $\begin{array}{l}\text { TLT-1 soluble form } \\
\text { correlated with DIC }\end{array}$ \\
\hline PEAR1 & $”$ & $\begin{array}{l}\text { Multiple EGF-like domain } \\
\text { protein }\end{array}$ & - & $\begin{array}{c}\text { Phosphorylated after } \\
\text { platelet contact }\end{array}$ \\
\hline \multicolumn{5}{|c|}{ Negative regulation } \\
\hline VPAC1 & Platelet plasma membrane & $\begin{array}{l}\text { G protein-coupled } \\
\text { receptors }\end{array}$ & PACAP & \\
\hline PECAM-1 & $"$ & Ig superfamily & $\begin{array}{l}\text { PECAM-1, collagen, } \\
\text { glycosaminoglycans }\end{array}$ & \\
\hline G6B-b & ” & $"$ & - & \\
\hline $\mathrm{PGI}_{2}$ receptor (IP) & $"$ & $\begin{array}{l}\text { G protein-coupled } \\
\text { receptors }\end{array}$ & $\mathrm{PGI}_{2}$ & $\begin{array}{l}\text { Prostacyclin released } \\
\text { from endothelial cells }\end{array}$ \\
\hline $\mathrm{PGD}_{2}$ receptor & $”$ & $"$ & $\mathrm{PGD}_{2}$ & \\
\hline $\mathrm{PGE}_{2}$ receptor $(\mathrm{EP} 4)$ & $"$ & $"$ & $\mathrm{PGE}_{2}$ & \\
\hline
\end{tabular}

TABLE 2: A comparison of endothelial and platelet properties (adapted from Warkentin et al., 2003 [21]).

\begin{tabular}{|c|c|c|}
\hline & Endothelium & Platelets \\
\hline Nucleus & Yes & No \\
\hline mRNA & Lots & Little but active \\
\hline Cell dimensions & $\begin{array}{l}\text { Highly variable: up to } 100 \mu \mathrm{M} \\
\text { length in large vessels }\end{array}$ & $\begin{array}{l}\text { Diameter } \sim 4 \mu \mathrm{M} \text {, volume } 7-12 \mathrm{fL} \\
\text { (inversely proportional to platelet count) }\end{array}$ \\
\hline Life span & Long (months to years) & Short (7-9 days) \\
\hline Daily production & Not known & $2.5 \times 10^{11}$ \\
\hline Circulating & Few & $\begin{array}{l}\text { Most (normally } 1 / 3 \text { sequestered in spleen; may become } \\
\text { sequestered on activated endothelium) }\end{array}$ \\
\hline Diagnostic markers & $\begin{array}{l}\text { Indirect and not clinically } \\
\text { useful }\end{array}$ & $\mathrm{CBC}$, peripheral smear, platelet function studies \\
\hline Origin & Bone marrow & Bone marrow \\
\hline Storage granules & Weibel-Palade bodies & $\alpha$ granules, dense granules, lysosomes \\
\hline Partial list of storage components & vWf, P-selectin, multimerin & $\begin{array}{l}\text { vWf, P-selectin, multimerin, fibrinogen, PDGF, TGF- } \beta \text {, IL-1, } \\
\text { VEGF, angiopoietin, RANTES, PF4, ADP, ATP, serotonin }\end{array}$ \\
\hline
\end{tabular}

the technique are very poor. And overall in case of low platelet count the result is very difficult to interpret. Thus this technique was almost replaced by flow cytometry assay $[5,6]$, which is far more convenient and perfect. Expression of several platelet markers such as CD62p (P-selectin) and CD63 is now being well studied using flow cytometry technique [33, 34]. PAC 1, a monoclonal (Figure 7) antibody with specific binding to the fibrinogen receptor of activated platelets, is now widely used to assess platelet activation. Platelet-bound antibodies were detected either by fluorescein isothiocyanate (FITC) or by phycoerythrin (PE) $[35,36]$.
As platelets are devoid of any nucleus, proteomics aids new therapeutic targets of many diseases with platelet dysfunction [37]. After obtaining platelet-rich plasma, platelets are isolated and simultaneously disrupted to analyze their proteomic contents. 1D or 2D gel electrophoresis is involved to separate the protein fractions where mass spectrometry can analyze the proteins. Further investigation involves the usage of Western blotting which will ultimately validate the obtained data. A researcher group found alteration in cytoskeleton as well as significant differences in ILK, GAPDH and PK in platelets from arterial thrombosis [38]. Another 
TABLE 3: Clinical assessment of platelet functions.

\begin{tabular}{|c|c|}
\hline \multicolumn{2}{|r|}{ Platelet aggregometry } \\
\hline Photo-optical platelet aggregometry [79] & Platelet-rich plasma is taken to check the platelet aggregation. \\
\hline Impedance platelet aggregometry $[80]$ & Platelet aggregation is checked by using the whole blood by electrical impedance. \\
\hline Light-scattering platelet aggregometry [81] & $\begin{array}{l}\text { It is a combination of laser light scattering and aggregometry to monitor platelet } \\
\text { microaggregate formation. }\end{array}$ \\
\hline \multicolumn{2}{|r|}{ Point-of-care for platelet function tests } \\
\hline $\begin{array}{l}\text { Ultegra rapid platelet function assay (RPFA) } \\
\text { [82] }\end{array}$ & $\begin{array}{l}\text { RPFA is a simple and fast, automated point-of-care device that monitors GPIIb-IIIa } \\
\text { inhibition. This test is based on platelet agglutination from interaction between } \\
\text { unblocked GPIIb-IIIa receptors and fibrinogen-coated beads. }\end{array}$ \\
\hline $\begin{array}{l}\text { Platelet-activating clotting test (PACT) assay } \\
\text { [83] }\end{array}$ & $\begin{array}{l}\text { The PACT assay, HemoSTATUS, measures ACT without a platelet activator, comparing it } \\
\text { with ACTs obtained with increasing concentrations of platelet-activating factor (PAF). }\end{array}$ \\
\hline Platelet function analyzer (PFA-100) [84] & $\begin{array}{l}\text { PFA-100 exposes platelets within citrated whole blood to high shear stress through a } \\
\text { capillary tube, followed by an aperture in a membrane coated with collagen and either } \\
\text { ADP or epinephrine. The platelets adhere and aggregate until the aperture is occluded, } \\
\text { and the time to this closure is recorded. }\end{array}$ \\
\hline Plateletworks test [85] & $\begin{array}{l}\text { The Plateletworks is a point-of-care test that uses a Coulter counter to measure } \\
\text { platelet-count ratio, red blood cell count, hemoglobin, and hematocrit. Platelet count is } \\
\text { measured in a control sample in which aggregation is prevented by EDTA and compared } \\
\text { with the platelet count in an agonist-stimulated (ADP or collagen) sample. }\end{array}$ \\
\hline Clot signature analyzer $[86]$ & $\begin{array}{l}\text { This test uses nonanticoagulated whole blood and can measure several aspects of platelet } \\
\text { function and clotting properties. }\end{array}$ \\
\hline Thromboelastography [87] & This device measures clot strength and gives a global assessment of hemostasis. \\
\hline
\end{tabular}

group found significant alteration in cytoskeleton, differential expression of Coronin-1B, PSB8, and pleckstrin, and upregulation of proteins associated with energy metabolism. Thus, proteomics assay could implicate a new horizon in platelet study [39].

2.5. Symptoms of Platelet Dysfunction and Clinical Assessment. Diagnosis of platelet function relies on clinical findings of both detailed medical history and family history. Some platelet disorders are hereditary where most of them are acquired due to various diseased conditions. An alteration in platelet function includes prolonged or excessive bleeding which is the primary screening procedure to assess platelet dysfunction. Change in platelet number and mean platelet volume are another indicating markers in platelet dysfunction. Some of the common symptoms include [40] the following:

(i) unexplained or extensive bruising particularly associated with soft tissue hematoma,

(ii) epistaxis, particularly lasting more than 30 minutes or causing anemia,

(iii) menorrhagia, particularly if present since menarche,

(iv) gingival bleeding,

(v) heavy and prolonged bleeding childbirth,

(vi) bleeding following invasive procedures (e.g., dental extraction, tonsillectomy, and adenoidectomy).

Clinically, platelet function is assessed either by checking platelet aggregation by taking the whole blood or platelet-rich plasma from the patients to the pathology lab or by point-ofcare (POC) platelet function test. The tests are summarized in (Table 3).

\section{Platelet Dysfunction in Disease Pathophysiology}

In recent times, platelets have emerged to be important markers for disease pathophysiology. They are multifunctional blood particles and very important clinical targets for many disease pathophysiology (Figure 8). Being important inflammatory markers, they play important roles in atherosclerosis and cardiovascular disorders which are correlated with type 2 diabetes. They have profound role in tumor biology as well as allergic inflammation. Thrombin, an agonist released by platelets has profound role in inflammation [41-44], angiogenesis [45] and embryonic development [46, 47].

\section{Platelet Dysfunction in Cardiovascular Disorder (CVD) and Diabetes}

Diabetes mellitus is heterogeneous, multifactorial, polygenic disease characterized by defect in insulin's secretion (the beta cell secretory defect) and action (insulin resistance) [48]. Type 2 which is the most prevalent form is basically a lifestyle disorder now becoming a major global threat. Obesity is the major cause of diabetes in the adults [49]. The most prevalent diabetic macrovascular complication is cardiovascular disorder [50]. BMI was significantly and linearly associated with systolic blood pressure, fasting glucose levels, plasma total cholesterol, VLDL cholesterol, and LDL cholesterol levels and was inversely and linearly associated with HDL cholesterol 


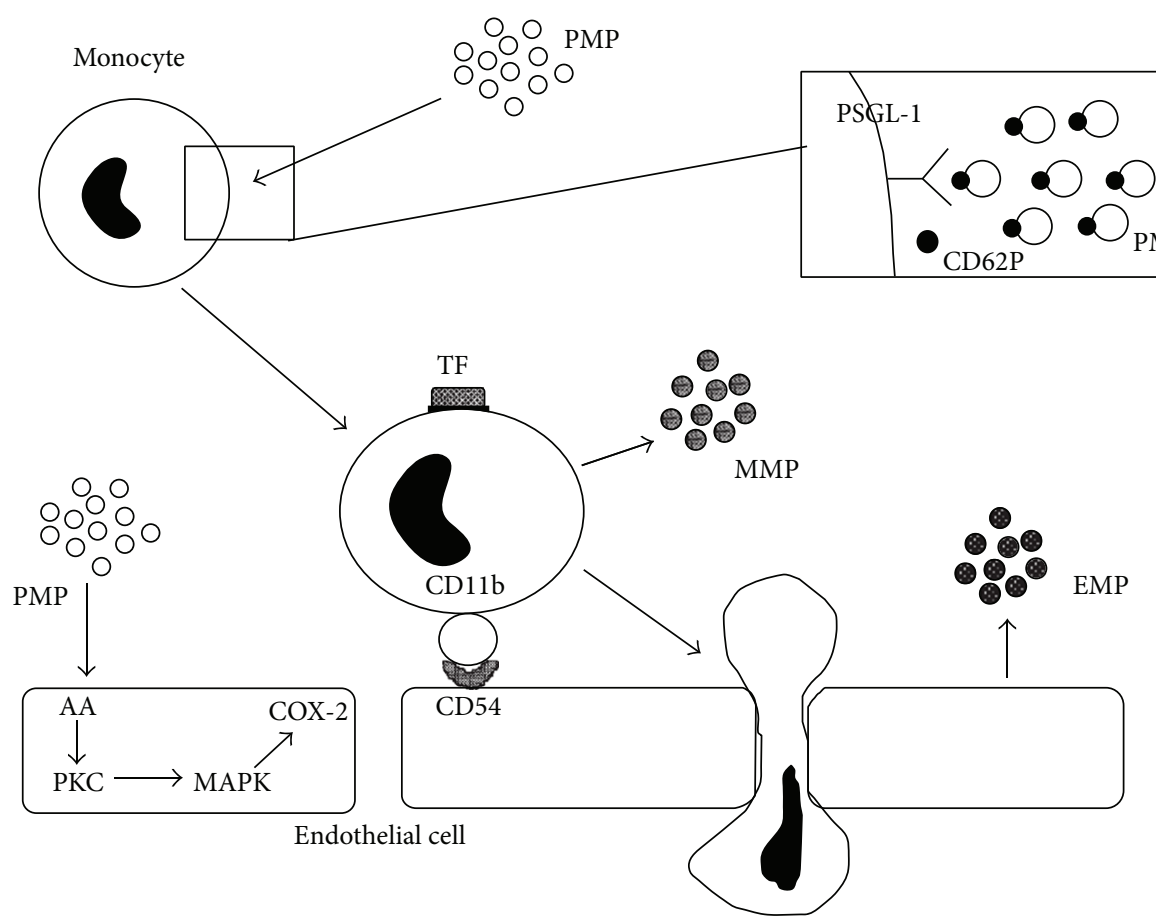

FIGURE 2: Mechanism of vascular changes by platelet-derived microparticles (PMPs). PMPs activate monocytes by a reaction between Pselectin and PSGL-1 (P-selectin glycoprotein ligand-1). Activated monocytes induce expression on the cell surface of tissue factor (TF) and CD11b. Activated monocytes also induce release of monocyte-derived microparticles (MMPs). PMPs induce COX-2 production in endothelial cells. PMPs enhance expression of CD54 (ICAM-1) on the endothelial surface. Activated endothelial cells also induce release of endothelial cell-derived microparticles (EMPs), enhancing adhesion between endothelial cells and monocytes. Finally, monocytes induce migration of endothelial cells, resulting in vascular changes. Abbreviations: arachidonic acid (AA); protein kinase C (PKC); mitogen-activated protein kinase (MAPK) (adapted from Nomura, 2001 [8]).

level [51], having a direct correlation in developing T2DM. Obesity is a key feature of metabolic syndrome, reflecting the fact that the syndrome's prevalence is driven by the strong relationship between body mass index (BMI) and increasing adiposity [52].

Our research group previously found hyperglycemiainduced oxidative stress in structural functional alterations of hemoglobin and red blood cells $[53,54]$. But there are limited reports to elucidate the altered behavior of platelets in different diseases, majorly focusing on diabetes and associated cardiovascular disorders which are major threats to society in recent times.

4.1. Hyperaggregation in Platelets. One of the most common changes in platelet behaviour in diseased condition, such as diabetes, is platelet hyperaggregation. In response to various agonists, hyperaggregation in platelets was reported in patients with both type 2 and type 1 diabetes mellitus [55, 56]. Hyperaggregation is associated with generating more 11dehydro-thromboxane $B_{2}$ which is the important end product of thromboxane pathway as discussed earlier (Figure 2). DM has been reported to increase the production of this product as well as prothrombin accelerating aggregation; this can increase the chances of CVD among diabetic patients, as hyperaggregated platelets have a tendency to block the blood vessels. By contrast, anticoagulant markers, such as activated protein $\mathrm{C}$, protein $\mathrm{C}$ activation peptide, and soluble thrombomodulin (TM), were depressed in T2DM, further increasing the chances of CVD [57].

4.2. Alterations in Thromboxane Production. Thromboxane is an important product which plays profound role in platelet aggregation. Studies showed that thromboxane production is enhanced in diabetes subjects compared to controls increasing platelet aggregation, indicating a higher risk of CVD [58-60]. To initiate aggregation, platelets from patients with $\mathrm{T} 2 \mathrm{DM}$ can synthesize greater amount of $\mathrm{TxB}_{2}$ but it requires less arachidonate, the precursor of thromboxane pathway and collagen, than from normal nondiabetic controls [61]. $\mathrm{TxA}_{2}$ production has been positively correlated with fasting plasma glucose and HbAlc; higher blood glucose increases the production of $\mathrm{TxA}_{2}$ which is an important product in thromboxane pathway. Several studies showed reduced $\mathrm{TxA}_{2}$ production in improved glycaemic controls $[58,62$, 63]. Data suggests that 8 -iso-PGF2 $\alpha$, a marker involved in lipid and arachidonate peroxidation; is correlated with $\mathrm{TxA}_{2}$ biosynthesis which could be a link between glycaemic control, oxidative stress, and platelet activation [64]. Thus alteration in thromboxane pathway can be a link between platelet dysfunction and diabetes, obesity, and CVD. 


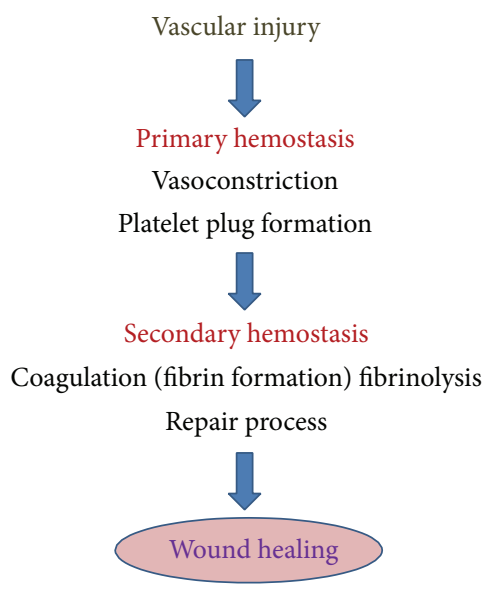

FIGURE 3: Pathway illustrating hemostasis.

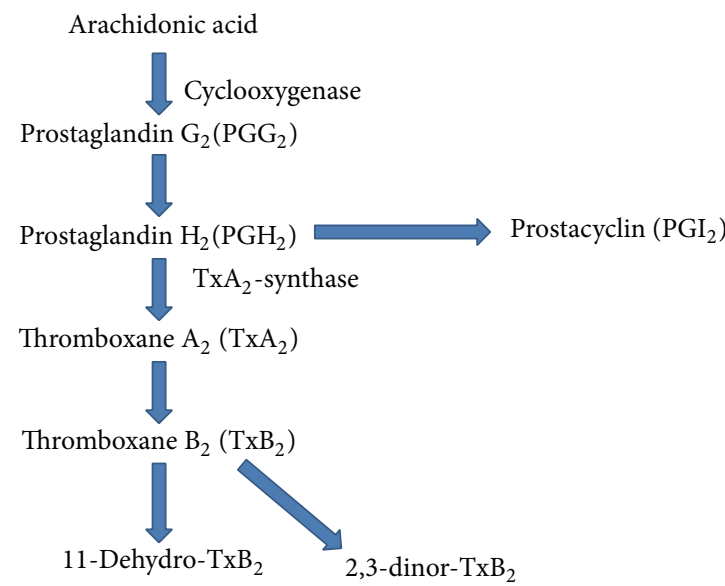

FIgURE 4: Thromboxane biosynthesis pathway.

4.3. Changes in Platelet Membrane Fluidity. Change in membrane fluidity has been assigned to the impairment of platelet functions since membrane fluidity can modulate cell function, and reduced membrane fluidity in cholesterol- enriched platelets is associated with platelet hypersensitivity to different agonists [65]. Due to glycation of membrane proteins, platelet membrane fluidity has been grossly impaired in diabetes. Decreased membrane fluidity of these platelets is attributed to an increased cholesterol-phospholipid molar ratio in platelet membranes. Reduced membrane fluidity is associated with hypersensitivity to thrombin in intact platelets from diabetic subjects $[66,67]$.

4.4. Altered Expression of Platelet Agonists. The number and adhesiveness of several platelet specific surface glycoprotein receptors (GP) are significantly enhanced in diabetic subjects. CD40 ligand on platelets has been correlated with HbAlc concentrations. An upregulation of the CD40-CD40 ligand system has been observed in patients with DM [68] along with an increase in GPIIb/IIIa, vWf, GPIa/IIa, P-selectin (CD62), and CD63 [69-72]. Patients suffering from ischemic heart disease (IHD) and depression concurrently may have abnormal platelet activation resulting in an increased risk of thrombosis. Mean PF4 and $\beta$-TG plasma levels in the IHD group with depression were found to be significantly higher than those of the control and IHD groups [73]. Moreover high vWf value may increase the chance of CVD [74] which can also act as an index for disease prediction.

Hyperglycemia induces downregulation of SIRT1 and upregulation of PAF-R in endothelial progenitor cells whose association is linked with vascular complications [75]. Platelet activity is correlated with nitric oxide (NO) synthesis, which is impaired in acute coronary syndrome (ACS). Significant differences of eNOS gene polymorphism and expression have been observed between diabetic patients with ACS and patients with ACS but no history of diabetes [76]. Platelet FcgammaRIIA is significantly overexpressed in type 2 diabetes whose interaction with collagen may alter platelet adhesion.

Several candidate gene polymorphisms have been associated with platelet functions. Polymorphisms of these genes may develop CAD, CVD, and ACS in both diabetic and nondiabetic subjects. Some of these genes are glycoprotein $\mathrm{Ia} / \mathrm{IIa}\left(\alpha^{2} \beta^{1}\right)(-807 \mathrm{C}>\mathrm{T}, 873 \mathrm{G}>\mathrm{A}-,-837 \mathrm{C}>\mathrm{T}, 1648 \mathrm{~A}>\mathrm{G})$, glycoprotein lb $\alpha$ (VNTR A-D), and glycoprotein IIb/IIIa (substitution of proline for leucine at position 33) [77]. However, alpha 2 integrin C807T gene polymorphism plays a crucial role in arterial thrombosis [78].

4.5. Changes in Mean Platelet Volume (MPV). MPV is machine generated average size of a platelet, whose value is enhanced in subjects with DM. An explanation of this phenomenon is that larger platelets are more reactive and can express more surface receptors $[88,89]$. Increased MPV value is associated with diabetic retinopathy. Event of myocardial infarction is positively correlated with MPV [90].

4.6. Alterations in Intracellular Ionic Environment. Platelet hyperactivity is associated with reduced $\mathrm{Na}^{+} / \mathrm{K}^{+}$ATPase and increased $\mathrm{Ca}^{2+}$ ATPase activity which can increase intracellular $\mathrm{Ca}^{2+}$ concentration, thus increasing platelet activity [91]. Moreover a decrease in intracellular $\mathrm{Mg}^{+}$concentration in diabetic platelets may provoke an accelerating effect in platelet activity [92]. Oxidative stress is associated with superoxide anion production and nitric oxide $(\mathrm{NO})$ synthesis as well as production of reduced glutathione. Hyperglycemia exerts oxidative stress which can further implement altered platelet functions [93].

4.7. Changes in Mitochondrial Membrane Potential. Studies have established that plasma glycated haemoglobin (HbAlc) level is positively correlated with platelet ATP content, suggesting that hyperglycemia promotes platelet mitochondria to generate more ATP, but decreases platelet mitochondrial potential [94].

4.8. Effect of Antidiabetic Drugs on Platelet Dysfunction. Apart from aspirin which is commonly used in diabetes mellitus, many widely used antidiabetic drugs also result in 


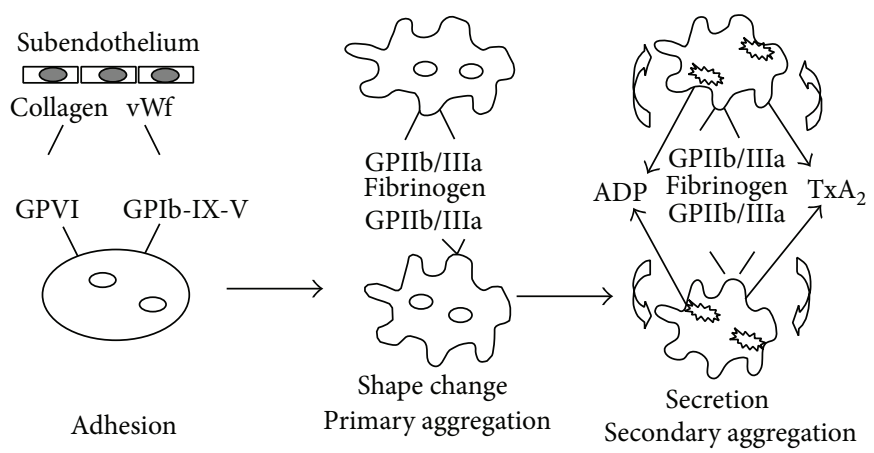

Figure 5: After an injury in the vessel wall, activation of platelets begins to start. It involves its adhesion to the subendothelium surface. Interaction between receptors like GPIb-V-IX, GPIa-IIa, and subendothelial compounds like $\mathrm{vWf}$ and collagen triggers the release of platelet granule contents accelerating aggregate formation.

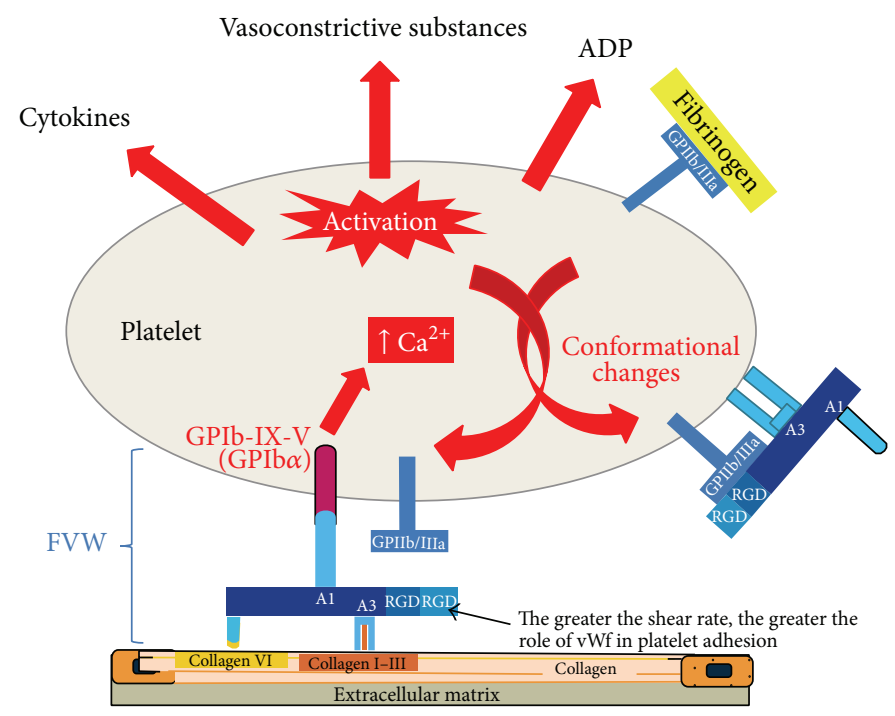

FIGURE 6: Diagram illustrating the role of von Willebrand factor (vWf) in platelet adhesion. High flow rates induce conformational changes in vWf allowing interaction of its A3 domain with matrix collagen. This induces a conformational change in the A1 domain, thereby allowing interaction with glycoprotein (GP) platelet receptor Ib-IX-V. This interaction stimulates calcium release, subsequent platelet activation, and subsequent conformational change of the fibrinogen receptor (GPIIb/IIIa), which can interact with fibrinogen and vWf to favor the interaction between platelets (platelet aggregation process). ADP indicates adenosine diphosphate; RGD and Arg-Gly-Asp are amino acid sequences (adapted from Badimon et al., 2009 [30]).

platelet malfunction. The majority of these drugs are presented hereunder.

4.8.1. Metformin. Metformin, an oral antidiabetic, first line drug of biguanide class, is particularly useful for overweight and obese diabetic patients. Chakraborty et al. reported that metformin is particularly useful to restore the antioxidant status of cells hampered in type 2 diabetes [95]. Metformin treatment also decreases ROS generation and creates mitochondrial membrane hyperpolarization lowering the risk of CVD [96]. Different researchers concluded that metformin can stabilize platelet by reducing platelet density, $\beta$-TG, and platelet superoxide anion production [97-99]. Metformin also helps to reduce PAI-1 in plasma, thus putting beneficial effects on fibrinolysis. By reducing FVII and FXIII, metformin also plays an important role in coagulation [100].
4.8.2. Sulfonylurea. Sulfonylurea derivatives are a class of antidiabetic drugs which act by increasing insulin release from the beta cells in the pancreas. Gliclazide, a sulfonylurea derivative, can check blood glucose level by its free radical scavenging ability. It also confers beneficial effects on the hemorrheologic abnormalities by reducing platelet abnormalities in diabetic patients by increasing prostacyclin synthesis [101]. Gliclazide can reduce platelet aggregation, enhance fibrinolysis, inhibit the surface expression of endothelial adhesion molecules, and inhibit neutrophil endothelial cell adhesion [102, 103].

4.8.3. Thiazolidinediones. Thiazolidinediones or glitazones activate PPAR $\gamma$ via FFA and eicosanoids. When activated, the receptor binds to DNA in complex with the retinoid X receptor (RXR) modifying the transcription of certain genes 


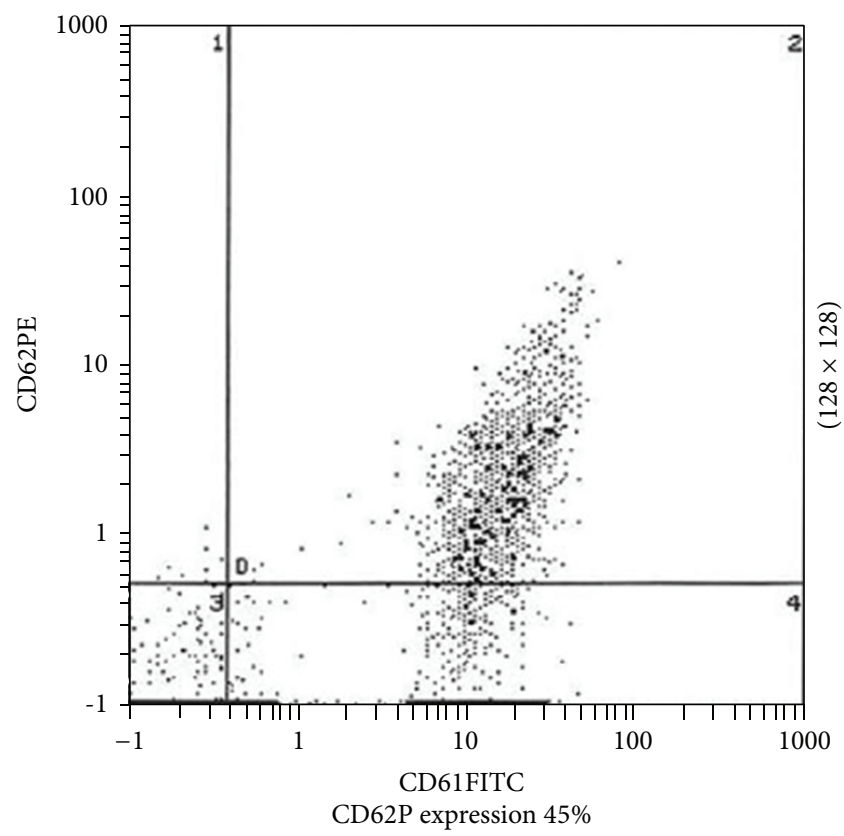

(a)

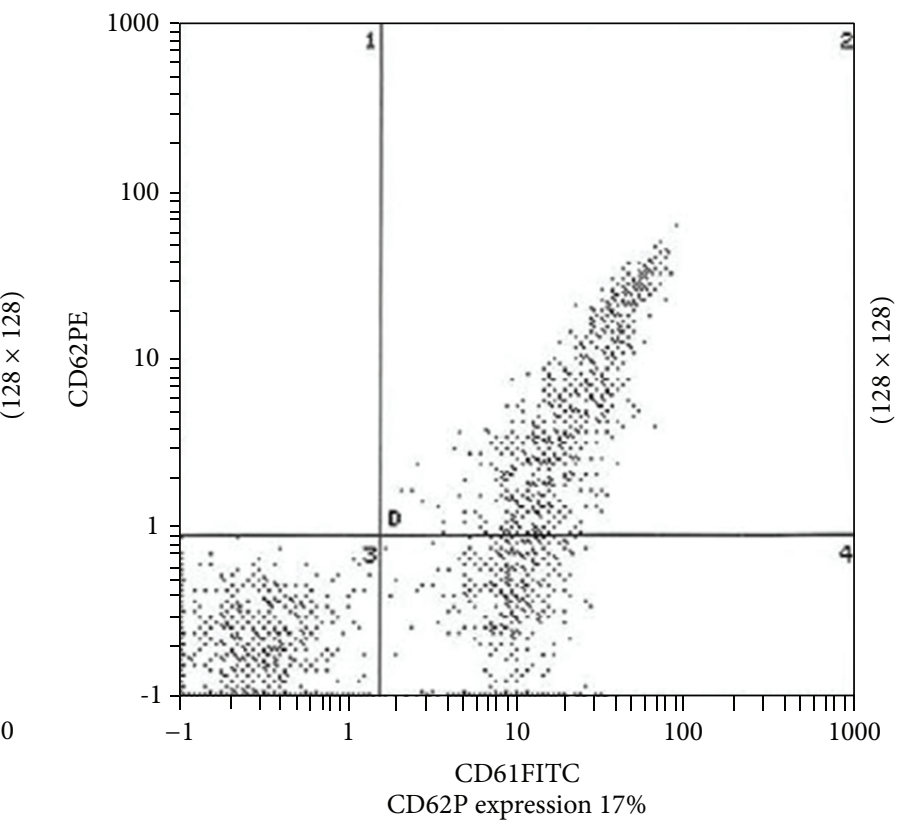

(b)

Figure 7: Flow cytometric detection of P-selectin in (a) diabetic patient and (b) nondiabetic patient (adapted from Saad et al., 2011 [34]).

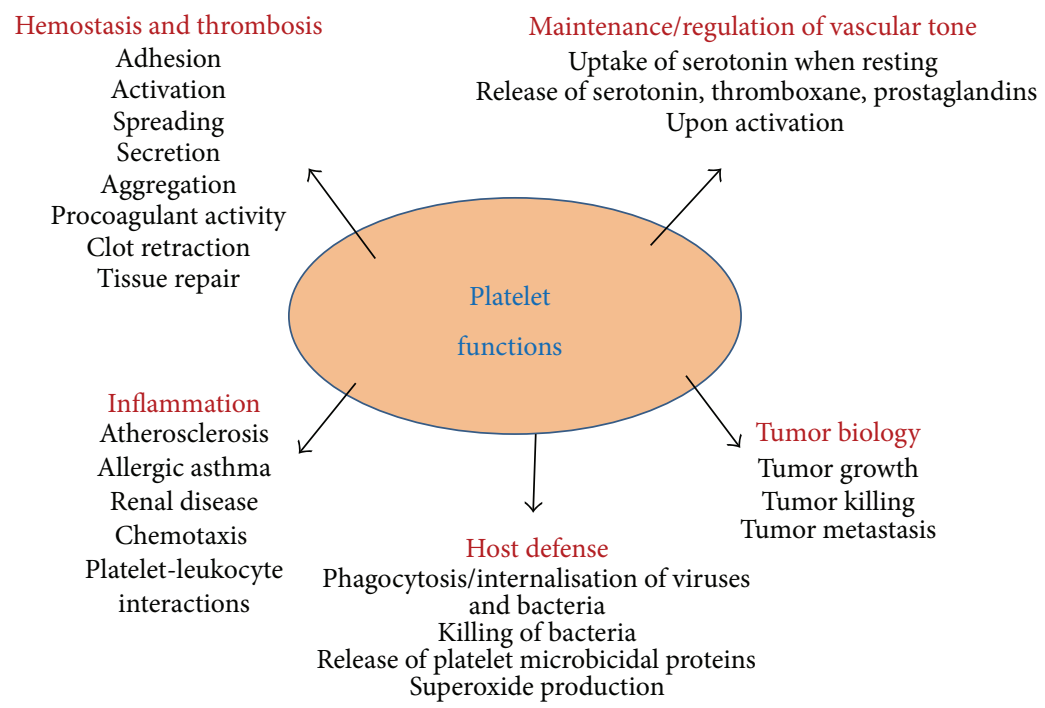

FIGURE 8: The multifunctional platelet (adapted from Harrison, 2005 [44]).

in several tissues including vascular tissue [104]. Platelets have profound role in inflammation due to their release of the proinflammatory and proatherogenic mediators: CD40 ligand (CD40L) and thromboxanes (TXs). Studies showed that platelet incubation with rosiglitazone prevented thrombininduced CD40L surface expression and release of CD40L and thromboxane $\mathrm{B}_{2}\left(\mathrm{TxB}_{2}\right)$ [105]. Administration of rosiglitazone has significantly reduced von Willebrand factor in one study [106]. Platelets from patients with type 2 diabetes mellitus lack platelet endothelial cell adhesion molecule-1. Rosiglitazone treatment has been found to increase platelet
SERCA-2 expression and $\mathrm{Ca}^{2+}$-ATPase activity. Moreover, it has inhibiting effect on SERCA-2 tyrosine nitration, thus normalizing platelet $\mathrm{Ca}^{2+}$ concentration. Rosiglitazone also reduces $\mu$-calpain activity, normalizes platelet endothelial cell adhesion molecule-1 levels, and partially restores platelet sensitivity to nitric oxide synthase inhibition [107].

4.8.4. Acarbose. Acarbose blocks carbohydrate digestion by inhibiting enzyme glycoside hydrolases. Acarbose is known to decrease platelet-monocyte aggregate formation by reducing postprandial hyperglycaemia in diabetic patients [108]. 
4.9. Effects of Insulin on Platelets. Insulin resistance and associated metabolic syndrome jointly correlate with prothrombic state in diabetes mellitus to put a cumulative effect in the progression of vascular complications [109]. Insulin has been reported to have antiplatelet effects. Researchers have identified a direct correlation between insulin-induced attenuation of the thrombin-induced $\mathrm{Ca}^{2+}$ response and platelet aggregation $[110,111]$. Diabetic platelet shows an altered $\mathrm{Ca}^{2+}$ homeostasis [112]. Tyrosine phosphorylation of platelet plasma membrane $\mathrm{Ca}^{2+}$-ATPase may serve as positive feedback to inhibit membrane $\mathrm{Ca}^{2+}$-ATPase and increase intracellular calcium during platelet activation [113].

Reports suggest that in nondiabetic patients with acute ischemic heart disease binding of $\mathrm{PGI}_{2}$ with insulin is lessened [114]. But insulin administration has normalized platelet activity to $\mathrm{PGI}_{2}$ in coronary heart diseases both in vitro and in vivo $[115,116]$. Vitamin $\mathrm{E}$ deficiency plays a crucial role in platelet aggregation, where $\alpha$-tocopherol supplementation in response to ADP decreases $\mathrm{TxA}_{2}$ [117]. Although several studies concluded the beneficial role of Vitamin E supplementation in diabetic patients with CVD, large scale study fails to conclude the minimization of myocardial infarction occurrence in diabetic patients [118]. Insulin therapy may improve platelet sensitivity to NO, thus providing a suitable platform in treating CVDs among diabetic patients.

\section{Platelet Dysfunction in Other Diseases}

5.1. Heart Disease. Not only diabetes related cardiovascular disorder but also platelet dysfunction has been reported in other heart diseases. It has been reported in many cases that patients with congestive heart failure (CHF) have increased risk of venous thromboembolism, stroke, and sudden death [119]. J. Mehta and P. Mehta first reported that patients with CHF have significantly higher number of circulating platelet aggregates than the normal subjects [120]. In one study, patients with left ventricular dysfunction have shown increased number of fibrin D-dimer, fibrinogen and vWf levels compared to healthy controls [121]. Patients with acute decompensated heart failure (AHF) show more abnormalities of platelet activation than stable CHF patients and healthy controls [122]. In heart failure, endothelial nitric oxide (NO) production is much lower where oxidative stress and NO degradation rate are much higher. Platelet has been shown to produce less bioactive NO in patients with heart failure, mainly due to the defect in the the platelet l-arginine/NO/guanylyl cyclase pathway [123]. Thus altered platelet activity can give major insights into heart disease and can be an interesting field to explore.

5.2. Renal Disease. Complex hemostatic disorders have been found in patients with end stage renal disease (ESRD) that may be in form of bleeding diatheses. Platelet dysfunctions result due to the presence of toxic products in the circulating blood. Dialysis improves this complication; however, it does not eliminate the risk of hemorrhage. Some common pathological features include thrombocytopenia, glomerular thrombosis, and thrombi in small arteries and glomerular capillaries [124]. Both intrinsic platelet abnormalities and impaired platelet-vessel wall interaction can contribute to platelet dysfunction [125]. In renal failure, the normal activation process of the platelets to form aggregates is impaired.

5.3. Cancer and Tumorigenesis. Platelet plays versatile role in cancer progression. The procoagulant environment provided by platelets can secure the coagulation of cancer cells, protecting them from immune system, thus prompting the formation of tumors [126]. Platelets facilitate tumor cell migration and invasiveness, prompting metastasis. It has been reported in both breast and ovarian cancer that platelets increase the invasiveness of cancer cells which can induce the further progression of the disease [127-129]. Moreover, tumor cells also have the ability to aggregate platelets [130], further increasing the chance of inducing metastasis. Activation of platelets and regulation of other cells have been controlled by thrombin by means of $\mathrm{G}$ protein-coupled protease-activated receptors (PARs) [131]. Researchers have shown that thrombin signaling also contributes hugely to the progression of tumorigenesis and angiogenesis [132].

5.4. Alzheimer's Disease. Platelet dysfunction has been also implicated in Alzheimer's disease (AD), which is the most common form of dementia. Platelet can store a huge amount of amyloid precursor protein (APP); recent finding shows that platelet APP metabolism may accumulate $\mathrm{A} \beta$ in the brain and its vasculature through the blood brain barrier [133]. Platelet $\alpha$-granules store RANTES, an inflammatory signaling molecule whose secretion from PBMC has been reported to increase in $\mathrm{AD}$ [134]. The fluidity of the hydrocarbon region of platelet membranes from the AD patients is significantly higher than that of control group [135]. Platelet secretases activities and COX enzyme activity (which is also a component in APP secretion pathway) have been impaired in platelets of $\mathrm{AD}$ patients, thus making this blood particle a suitable marker of this disease [136].

5.5. Liver Disease. Quantitative and qualitative platelet defects, hyperfibrinolysis, accelerated intravascular coagulation, and decreased synthesis of clotting and inhibitor factors are well observed in both acute and chronic liver diseases [137]. As most coagulation factors except vWf are synthesized by liver parenchymal cells, and liver's reticuloendothelial system plays crucial role in the clearance of activation products, a defect in liver function may alter hemostasis $[138,139]$. Not only functions but platelet numbers also have been reported to decrease in liver diseases [140]. It has been reported that platelet transfusion can improve liver function in patients with chronic liver disease and cirrhosis [141]. Platelets morphological parameters have been also reported to alter in liver diseases [142], thus providing a platform for platelet research in liver diseases.

\section{Conclusion}

Biomarkers are now emerging with immense scientific and clinical value through the whole journey of the disease 
process. Before diagnosis, markers can be used for prediction, screening, and risk assessment. During diagnosis, markers can determine staging, grading, and selection of initial drug therapy. During treatment, markers are used to monitor the prognosis of therapy or to select additional treatment needed. Platelet indices indicating differential dysfunction, hyperactivation, aggregation, or adhesion are capable of expressing the characters of disease pathogenesis. Accurate determination of platelet indices is cost effective and their impaired function can be correlated with the inflammation involved in diseased state. Thus, an attempt to identify different platelet biomarkers is of significant impact on the global scene of clinical application and development.

\section{Conflict of Interests}

The authors declare that there is no conflict of interests regarding the publication of this paper.

\section{Acknowledgement}

The authors acknowledge Council of Scientific and Industrial Research, Government of India, for providing research fellowship to Ms. K. Ghoshal.

\section{References}

[1] D. Ribatti and E. Crivellato, "Giulio Bizzozero and the discovery of platelets," Leukemia Research, vol. 31, no. 10, pp. 1339-1341, 2007.

[2] C. Cerletti, C. Tamburrelli, B. Izzi, F. Gianfagna, and G. de Gaetano, "Platelet-leukocyte interactions in thrombosis," Thrombosis Research, vol. 129, no. 3, pp. 263-266, 2012.

[3] A. I. Vinik, T. Erbas, T. Sun Park, R. Nolan, and G. L. Pittenger, "Platelet dysfunction in type 2 diabetes," Diabetes Care, vol. 24, no. 8, pp. 1476-1485, 2001.

[4] G. Sharma and J. S. Berger, "Platelet activity and cardiovascular risk in apparently healthy individuals: a review of the data," Journal of Thrombosis and Thrombolysis, vol. 32, no. 2, pp. 201208, 2011.

[5] A. D. Michelson, "Flow cytometry: a clinical test of platelet function," Blood, vol. 87, no. 12, pp. 4925-4936, 1996.

[6] H. M. Rinder, "P latelet function testing by flow cytometry," Clinical Laboratory Science, vol. 11, pp. 365-372, 1998.

[7] R. F. Storey, "New developments in antiplatelet therapy," European Heart Journal, Supplement, vol. 10, pp. D30-D37, 2008.

[8] S. Nomura, "Function and clinical significance of plateletderived microparticles," International Journal of Hematology, vol. 74, no. 4, pp. 397-404, 2001.

[9] P. Blair and R. F. laumenhaft, "P latelet alpha-granules: basic biology and clinical correlates," Blood Reviews, vol. 23, pp. 177189, 2009.

[10] S. Offermanns, "Activation of platelet function through G protein-coupled receptors," Circulation Research, vol. 99, no. 12, pp. 1293-1304, 2006.

[11] J. W. Heemskerk, E. M. Bevers, and T. Lindhout, "P latelet activation and bloo d coagulation," Thrombosis and Haemostasis, vol. 88, pp. 186-193, 2002.
[12] O. Behnke and A. Forer, "From megakaryocytes to platelets: platelet morphogenesis takes place in the bloodstream," European Journal of Haematology, Supplement, vol. 60, no. 61, pp. 324, 1998.

[13] A. D. Michelson, "Thrombin-induced down-regulation of the platelet membrane glycoprotein Ib-IX complex," Seminars in Thrombosis and Hemostasis, vol. 18, no. 1, pp. 18-27, 1992.

[14] J. G. White, "Interaction of membrane systems in blood platelets," American Journal of Pathology, vol. 66, no. 2, pp. 295312, 1972.

[15] L. F. Brass, J. A. Hoxie, and D. R. Manning, "Signaling through $G$ proteins and $G$ protein-coupled receptors during platelet activation," Thrombosis and Haemostasis, vol. 70, no. 1, pp. 217$223,1993$.

[16] R. Flaumenhaft, "Molecular basis of platelet granule secretion," Arteriosclerosis, Thrombosis, and Vascular Biology, vol. 23, no. 7, pp. 1152-1160, 2003.

[17] T. G. Diacovo, S. J. Roth, J. M. Buccola, D. F. Bainton, and T. A. Springer, "Neutrophil rolling, arrest, and transmigration across activated, surface-adherent platelets via sequential action of Pselectin and the $\beta 2$ - integrin CD11b/CD18," Blood, vol. 88, no. 1, pp. 146-157, 1996.

[18] J. Folkman, T. Browder, and J. Palmblad, "Angiogenesis research: guidelines for translation to clinical application," Thrombosis and Haemostasis, vol. 86, no. 1, pp. 23-33, 2001.

[19] J. N. Thon and J. E. Italiano, "P latelets: production, morphology and ultrastructure," Handbook of Experimental Pharmacology, no. 210, pp. 3-22, 2012.

[20] A. Kauskot and M. F. Hoylaerts, "P latelet receptors," Handbook of Experimental Pharmacology, no. 210, pp. 23-57, 2012.

[21] T. E. Warkentin, W. C. Aird, and J. H. Rand, "Platelet-endothelial interactions: sepsis, HIT, and antiphospholipid syndrome," Hematology, pp. 497-519, 2003.

[22] Y. Lin, D. J. Weisdorf, A. Solovey, and R. P. Hebbel, "Origins of circulating endothelial cells and endothelial outgrowth from blood," Journal of Clinical Investigation, vol. 105, no. 1, pp. 71-77, 2000.

[23] M. Félétou, Y. Huang, and P. M. Vanhoutte, "Endotheliummediated control of vascular tone: COX-1 and COX-2 products," British Journal of Pharmacology, vol. 164, no. 3, pp. 894912, 2011.

[24] T. Corazzi, M. Leone, R. Maucci, L. Corazzi, and P. Gresele, "Direct and irreversible inhibition of cyclooxygenase-1 by nitroaspirin (NCX 4016)," Journal of Pharmacology and Experimental Therapeutics, vol. 315, no. 3, pp. 1331-1337, 2005.

[25] W. L. Smith, D. L. DeWitt, and R. M. Garavito, "Cyclooxygenases: structural, cellular, and molecular biology," Annual Review of Biochemistry, vol. 69, pp. 145-182, 2000.

[26] C. Patrono, G. Ciabattoni, E. Pinca et al., "Low dose aspirin and inhibition of thromboxane B2 production in healthy subjects," Thrombosis Research, vol. 17, pp. 317-327, 1980.

[27] J. Lecka, M. S. Rana, and J. Sévigny, "Inhibition of vascular ectonucleotidase activities by the pro-drugs ticlopidine and clopidogrel favours platelet aggregation," British Journal of Pharmacology, vol. 161, no. 5, pp. 1150-1160, 2010.

[28] M. Yngen, C.-G. Östenson, N. Li, P. Hjemdahl, and N. H. Wallén, "Acute hyperglycemia increases soluble P-selectin in male patients with mild diabetes mellitus," Blood Coagulation and Fibrinolysis, vol. 12, no. 2, pp. 109-116, 2001.

[29] I. C. A. Munnix, J. M. E. M. Cosemans, J. M. Auger, and J. W. M. Heemskerk, "Platelet response heterogeneity in thrombus 
formation," Thrombosis and Haemostasis, vol. 102, no. 6, pp. 1149-1156, 2009.

[30] L. Badimon, G. Vilahur, and T. Padro, "Lipoproteins, platelets and atherothrombosis," Revista Española de Cardiología, vol. 62, pp. 1161-1178, 2009.

[31] R. J. Gryglewski, R. M. Botting, and J. R. Vane, "Mediators produced by the endothelial cell," Hypertension, vol. 12, no. 6, pp. 530-548, 1988.

[32] P. Harrison, I. Mackie, A. Mumford et al., "Guidelines for the laboratory investigation of heritable disorders of platelet function," British Journal of Haematology, vol. 155, no. 1, pp. 30-44, 2011.

[33] K. Fukunaga, T. Shimoyama, K. Yamaji, S. Yamane, A. Sueoka, and Y. Nosé, "In vitro comparison study of CD63 and CD62P expression after contacting leukocyte filters," Artificial Organs, vol. 23, no. 1, pp. 108-113, 1999.

[34] A. A. Saad, E. A. Ismail, Y. W. Darwish et al., "P latelet function profile post-clopidogrel therapy in patients with type 2 diabetes undergoing coronary stent implantation," Clinical and Applied Thrombosis/Hemostasis, vol. 18, pp. 249-257, 2012.

[35] S. J. Shattil, M. Cunningham, and J. A. Hoxie, "Detection of activated platelets in whole blood using activation-dependent monoclonal antibodies and flow cytometry," Blood, vol. 70, no. 1, pp. 307-315, 1987.

[36] M. H. Ginsberg, A. L. Frelinger, S. C.-T. Lam et al., "Analysis of platelet aggregation disorders based on flow cytometric analysis of membrane glycoprotein IIb-IIIa with conformation-specific monoclonal antibodies," Blood, vol. 76, no. 10, pp. 2017-2023, 1990.

[37] A. F. Parguina, I. Rosa, and A. Garcia, "P roteomics applied to the study of platelet- related diseases: aiding the discovery of novel platelet biomarker s and drug targets," Journal of Proteomics, vol. 76, pp. 275-286, 2012.

[38] E. G. Arias-Salgado, S. Larrucea, N. Butta et al., "Variations in platelet protein associated with arterial thrombosis," Thrombosis Research, vol. 122, no. 5, pp. 640-647, 2008.

[39] C. Banfi, M. Brioschi, G. Marenzi et al., "Proteome of platelets in patients with coronary artery disease," Experimental Hematology, vol. 38, no. 5, pp. 341-350, 2010.

[40] A. A. Sharathkumar and A. Shapiro, "Platelet function disorders," Treatment For Hemophilia, vol. 19, 2008.

[41] C. A. McNamara, I. J. Sarembock, L. W. Gimple, J. W. Fenton II, S. R. Coughlin, and G. K. Owens, "Thrombin stimulates proliferation of cultured rat aortic smooth muscle cells by a proteolytically activated receptor," Journal of Clinical Investigation, vol. 91, no. 1, pp. 94-98, 1993.

[42] C. T. Griffin, Y. Srinivasan, Y.-W. Zheng, W. Huang, and S. R. Coughlin, "A role for thrombin receptor signaling in endothelial cells during embryonic development," Science, vol. 293, no. 5535, pp. 1666-1670, 2001.

[43] A. J. Connolly, H. Lshihara, M. L. Kahn, R. V. Farese Jr., and S. R. Coughlin, "Role of the thrombin receptor an development and evidence for a second receptor," Nature, vol. 381, no. 6582, pp. 516-519, 1996.

[44] P. Harrison, "P latelet function analysis," Blood Reviews, vol. 19, pp. 111-123, 2005.

[45] J. Kisucka, C. E. Butterfield, D. G. Duda et al., "Platelets and platelet adhesion support angiogenesis while preventing excessive hemorrhage," Proceedings of the National Academy of Sciences of the United States of America, vol. 103, no. 4, pp. 855860, 2006.
[46] M. J. Paidas, M. J. Haut, and C. J. Lockwood, "Platelet disorders in pregnancy: implications for mother and fetus," Mount Sinai Journal of Medicine, vol. 61, no. 5, pp. 389-403, 1994.

[47] J. L. Clements, J. R. Lee, B. Gross et al., "Fetal hemorrhage and platelet dysfunction in SLP-76-deficient mice," Journal of Clinical Investigation, vol. 103, no. 1, pp. 19-25, 1999.

[48] M. R. Hayden, "Islet amyloid, metabolic syndrome, and the natural progressive history of type 2 diabetes mellitus," Journal of the Pancreas, vol. 3, no. 5, pp. 126-138, 2002.

[49] D. Parmar, K. Vidja, and B. Ghugare, "Impact of duration of diabetes and age: on lipid profile and glycaemic control in type 2 diabetic patients," Journal of International Medical Research, vol. 2, no. 1, pp. 69-72, 2013.

[50] W. T. Cade, "Diabetes-related microvascular and macrovascular diseases in the physical therapy setting," Physical Therapy, vol. 88, no. 11, pp. 1322-1335, 2008.

[51] S. Lamon-Fava, P. W. F. Wilson, and E. J. Schaefer, "Impact of body mass index on coronary heart disease risk factors in men and women: the Framingham Offspring Study," Arteriosclerosis, Thrombosis, and Vascular Biology, vol. 16, no. 12, pp. 1509-1515, 1996.

[52] A. Chakraborty and M. Bhattacharyya, "Diabetes, hypertension and cardiovascular disease - an unsolved enigma," in Phytotherapy in the Management of Diabetes and Hypertension, pp. 85-119, 2012.

[53] A. Saha, S. Adak, S. Chowdhury, and M. Bhattacharyya, "Enhanced oxygen releasing capacity and oxidative stress in diabetes mellitus and diabetes mellitus-associated cardiovascular disease: a comparative study," Clinica Chimica Acta, vol. 361, no. 1-2, pp. 141-149, 2005.

[54] S. Adak, S. Chowdhury, and M. Bhattacharyya, "Dynamic and electrokinetic behavior of erythrocyte membrane in diabetes mellitus and diabetic cardiovascular disease," Biochimica et Biophysica Acta, vol. 1780, no. 2, pp. 108-115, 2008.

[55] A. Hughes, B. A. McVerry, L. Wilkinson, A. H. Goldstone, D. Lewis, and A. Bloom, "Diabetes, a hypercoagulable state? Haemostatic variables in newly diagnosed type 2 diabetic patients," Acta Haematologica, vol. 69, no. 4, pp. 254-259, 1983.

[56] M. H. Rosove, H. J. L. Frank, and S. S. L. Harwig, "Plasma $\beta$ thromboglobulin, platelet factor 4 , fibrinopeptide $\mathrm{A}$, and other hemostatic functions during improved, short-term glycemic control in diabetes mellitus," Diabetes Care, vol. 7, no. 2, pp. 174179, 1984

[57] R. de Cristofaro, B. Rocca, E. Vitacolonna et al., "Lipid and protein oxidation contribute to a prothrombotic state in patients with type 2 diabetes mellitus," Journal of Thrombosis and Haemostasis, vol. 1, no. 2, pp. 250-256, 2003.

[58] R. K. Mayfield, P. V. Halushka, and H. J. Wohltmann, "Platelet function during continuous insulin infusion treatment in insulin-dependent diabetic patients," Diabetes, vol. 34, no. 11, pp. 1127-1133, 1985.

[59] P. V. Halushka, R. Mayfield, H. J. Wohltmann et al., "Increased platelet arachidonic acid metabolism in diabetes mellitus," Diabetes, vol. 30, no. 2, pp. 44-48, 1981.

[60] L. Tomaselli, C. Cerletti, G. de Gaetano, A. Notarbartolo, G. Davi, and M. Pupillo, "Normal platelet function, but increased platelet activation in vivo in diabetic patients," Thrombosis and Haemostasis, vol. 64, no. 4, p. 604, 1990.

[61] P. V. Halushka, R. C. Rogers, C. B. Loadholt, and J. A. Colwell, "Increased platelet thromboxane synthesis in diabetes mellitus," Journal of Laboratory and Clinical Medicine, vol. 97, no. 1, pp. 87-96, 1981. 
[62] J. W. D. McDonald, J. Dupre, N. W. Rodger, M. C. Champion, C. D. Webb, and M. Ali, "Comparison of platelet thromboxane synthesis in diabetic patients on conventional insulin therapy and continuous insulin infusions," Thrombosis Research, vol. 28, no. 6, pp. 705-712, 1982.

[63] G. Davi, I. Catalano, M. Averna et al., "Thromboxane biosynthesis and platelet function in type II diabetes mellitus," The New England Journal of Medicine, vol. 322, no. 25, pp. 1769-1774, 1990.

[64] G. Davi, G. Ciabattoni, A. Consoli et al., "In vivo formation of 8-iso-prostaglandin and platelet activation in diabetes mellitus: effects of improved metabolic control and vitamin E supplementation," Circulation, vol. 99, no. 2, pp. 224-229, 1999.

[65] P. D. Winocour, M. Bryszewska, C. Watala et al., "Reduced membrane fluidity in platelets from diabetic patients," Diabetes, vol. 39, no. 2, pp. 241-244, 1990.

[66] P. D. Winocour, C. Watala, and R. L. Kinglough-Rathbone, "Membrane fluidity is related to the extent of glycation of proteins, but not to alterations in the cholesterol to phospholipid molar ratio in isolated platelet membranes from diabetic and control subjects," Thrombosis and Haemostasis, vol. 67, no. 5, pp. 567-571, 1992.

[67] P. D. Winocour, C. Watala, D. W. Perry, and R. L. KinloughRathbone, "Decreased platelet membrane fluidity due to glycation or acetylation of membrane proteins," Thrombosis and Haemostasis, vol. 68, no. 5, pp. 577-582, 1992.

[68] Y. Jinchuan, W. Zonggui, C. Jinming, L. Li, and K. Xiantao, "Upregulation of CD40-CD40 ligand system in patients with diabetes mellitus," Clinica Chimica Acta, vol.339, no. 1-2, pp. 8590, 2004.

[69] D. Tschoepe, P. Roesen, L. Kaufmann et al., "Evidence for abnormal platelet glycoprotein expression in diabetes mellitus," European Journal of Clinical Investigation, vol. 20, no. 2, pp. 166-170, 1990.

[70] D. Tschoepe, E. Driesch, B. Schwippert, H.-K. Nieuwenhuis, and F. A. Gries, "Exposure of adhesion molecules on activated platelets in patients with newly diagnosed IDDM is not normalized by near-normoglycemia," Diabetes, vol. 44, no. 8, pp. 890894, 1995.

[71] B. Jilma, P. Fasching, C. Ruthner et al., "Elevated circulating Pselectin in insulin dependent diabetes mellitus," Thrombosis and Haemostasis, vol. 76, no. 3, pp. 328-332, 1996.

[72] N. Eibl, W. Krugluger, G. Streit, K. Schrattbauer, P. Hopmeier, and G. Schernthaner, "Improved metabolic control decreases platelet activation markers in patients with type-2 diabetes," European Journal of Clinical Investigation, vol. 34, no. 3, pp. 205209, 2004.

[73] F. Laghrissi-Thode, W. R. Wagner, B. G. Pollock, P. C. Johnson, and M. S. Finkel, "Elevated platelet factor 4 and $\beta$ thromboglobulin plasma levels in depressed patients with ischemic heart disease," Biological Psychiatry, vol. 42, no. 4, pp. 290-295, 1997.

[74] S. G. Thompson, J. Kienast, S. D. M. Pyke et al., "Hemostatic factors and the risk of myocardial infarction or sudden death in patients with angina pectoris," The New England Journal of Medicine, vol. 332, no. 10, pp. 635-641, 1995.

[75] M. L. Balestrieri, L. Servillo, A. Esposito et al., "Poor glycaemic control in type 2 diabetes patients reduces endothelial progenitor cell number by influencing S IRT1 signalling via plateletactivating factor receptor activation," Diabetologia, vol. 56, pp. $162-172,2013$.
[76] C. Fatini, E. Sticchi, P. Bolli et al., "Platelet aggregability is modulated by eNOS locus in non-type 2 diabetic patients with acute coronary syndrome," Nutrition, Metabolism and Cardiovascular Diseases, vol. 21, no. 1, pp. 11-17, 2011.

[77] M. S. Williams, E. J. Weiss, M. S. Sabatine et al., "Genetic regulation of platelet receptor expression and function: application in clinical practice and drug development," Arteriosclerosis, Thrombosis, and Vascular Biology, vol. 30, no. 12, pp. 2372-2384, 2010.

[78] D. C. Calverley, L. V. Baldermann, K. Moran, N. N. Chen, and K. Mcfann, "Platelet Fc $\gamma$ RIIA expression is associated with the $\alpha 2$ integrin C807T gene polymorphism in type 2 diabetes," Platelets, vol. 17, no. 2, pp. 78-83, 2006.

[79] G. V. Born and M. J. Cross, "The aggregation of blood platelets," The Journal of physiology, vol. 168, pp. 178-195, 1963.

[80] D. C. Cardinal and R. J. Flower, “The electronic aggregometer: a novel device for assessing platelet behavior in blood," Journal of Pharmacological Methods, vol. 3, no. 2, pp. 135-158, 1980.

[81] K. Satoh, Y. Ozaki, and S. Kume, "Detection of platelet aggregates using light scattering," Rinsho Byori, vol. 43, no. 5, pp. 426431, 1995.

[82] B. S. Coller, D. Lang, and L. E. Scudder, "Rapid and simple platelet function assay to assess glycoprotein IIb/IIIa receptor blockade," Circulation, vol. 95, no. 4, pp. 860-867, 1997.

[83] G. J. Despotis, V. Levine, K. S. Filos et al., "Evaluation of a new point-of-care test that measures PAF-mediated acceleration of coagulation in cardiac surgical patients," Anesthesiology, vol. 85, no. 6, pp. 1311-1323, 1996.

[84] S. K. Kundu, E. J. Heilmann, R. Sio, C. Garcia, R. M. Davidson, and R. A. Ostgaard, "Description of an in vitro platelet function analyzer-PFA-100," Seminars in Thrombosis and Hemostasis, vol. 21, supplement 2, pp. 106-112, 1995.

[85] N. S. Nicholson, S. G. Panzer-Knodle, N. F. Haas et al., "Assessment of platelet function assays," American Heart Journal, vol. 135, no. 5, pp. S170-S178, 1998.

[86] C. K. N. Li, T. J. Hoffmann, P.-Y. Hsieh, S. Malik, and W. Watson, "Xylum CSA: automated system for assessing hemostasis in simulated vascular flow," Clinical Chemistry, vol. 43, no. 9, pp. 1788-1790, 1997.

[87] S. V. Mallett and D. J. A. Cox, “Thrombelastography," British Journal of Anaesthesia, vol. 69, no. 3, pp. 307-313, 1992.

[88] D. Tschoepe, "The activated megakaryocyte-platelet-system in vascular disease: focus on diabetes," Seminars in Thrombosis and Hemostasis, vol. 21, no. 2, pp. 152-160, 1995.

[89] M. Tavassoli, "Megakaryocyte-platelet axis and the process of platelet formation and release," Blood, vol. 55, no. 4, pp. 537-545, 1980.

[90] J. F. Martin, P. M. W. Bath, and M. L. Burr, "Influence of platelet size on outcome after myocardial infarction," The Lancet, vol. 338, no. 8780, pp. 1409-1411, 1991.

[91] Y. Li, V. Woo, and R. Bose, "Platelet hyperactivity and abnormal $\mathrm{CA}^{2+}$ homeostasis in diabetes mellitus," American Journal of Physiology-Heart and Circulatory Physiology, vol. 280, no. 4, pp. H1480-H1489, 2001.

[92] J. L. Nadler, S. Malayan, H. Luong, S. Shaw, R. D. Natarajan, and R. K. Rude, "Intracellular free magnesium deficiency plays a key role in increased platelet reactivity in type II diabetes mellitus," Diabetes Care, vol. 15, no. 7, pp. 835-841, 1992.

[93] A. Ceriello, R. Giacomello, G. Stel et al., "Hyperglycemiainduced thrombin formation in diabetes: the possible role of oxidative stress," Diabetes, vol. 44, no. 8, pp. 924-928, 1995. 
[94] X. Guo, J. Wu, J. Du, J. Ran, and J. Xu, "Platelets of type 2 diabetic patients are characterized by high ATP content and low mitochondrial membrane potential," Platelets, vol. 20, pp. 588593, 2009.

[95] A. Chakraborty, S. Chowdhury, and M. Bhattacharyya, "Effect of metformin on oxidative stress, nitrosative stress and inflammatory biomarkers in type 2 diabetes patients," Diabetes Research and Clinical Practice, vol. 93, no. 1, pp. 56-62, 2011.

[96] A. Chakraborty, T. Karmakar, S. Chowdhury, and M. Bhattacharyya, "Effect of Metformin on pathological indices related to cardiovascular disease in diabetes," The American Journal of Bio-pharmacology Biochemistry and Life Sciences, vol. 1, pp. 5364, 2012.

[97] A. Collier, H. H. K. Watson, A. W. Patrick, C. A. Ludlam, and B. F. Clarke, "Effect of glycaemic control, metformin and gliclazide on platelet density and aggregability in recently diagnosed type 2 (non-insulin-dependent) diabetic patients," Diabete et Metabolisme, vol. 15, no. 6, pp. 420-425, 1989.

[98] F. Gregorio, F. Ambrosi, S. Manfrini et al., "Poorly controlled elderly Type 2 diabetic patients: the effects of increasing sulphonylurea dosages or adding metformin," Diabetic Medicine, vol. 16, no. 12, pp. 1016-1024, 1999.

[99] P. Gargiulo, D. Caccese, P. Pignatelli et al., "Metformin decreases platelet superoxide anion production in diabetic patients," Diabetes/Metabolism Research and Reviews, vol. 18, no. 2, pp. 156-159, 2002.

[100] P. J. Grant, "Beneficial effects of metformin on haemostasis and vascular function in man," Diabetes and Metabolism, vol. 29, no. 4, pp. S6-S44, 2003.

[101] P. E. Jennings, "Vascular benefits of gliclazide beyond glycemic control," Metabolism, vol. 49, no. 10, pp. 17-20, 2000.

[102] J. A. Colwell, "Introduction: oral treatment of diabetes mellitus: the contribution of gliclazide," American Journal of Medicine, vol. 90, pp. 1S-2S, 1991.

[103] M. Itoh, H. Omi, M. Okouchi et al., "The mechanisms of inhibitory actions of gliclazide on neutrophils-endothelial cells adhesion and surface expression of endothelial adhesion molecules mediated by a high glucose concentration," Journal of Diabetes and its Complications, vol. 17, no. 1, pp. 22-26, 2003.

[104] H. Hauner, "The mode of action of thiazolidinediones," Diabetes/Metabolism Research and Reviews, vol. 18, supplement 2, pp. S10-S15, 2002.

[105] F. Akbiyik, D. M. Ray, K. F. Gettings, N. Blumberg, C. W. Francis, and R. P. Phipps, "Human bone marrow megakaryocytes and platelets express $\operatorname{PPAR} \gamma$, and $\operatorname{PPAR} \gamma$ agonists blunt platelet release of CD40 ligand and thromboxanes," Blood, vol. 104, no. 5, pp. 1361-1368, 2004.

[106] J. S. Sidhu, D. Cowan, and J. C. Kaski, "Effects of Rosiglitazone on endothelial function in men with coronary artery disease without diabetes mellitus," American Journal of Cardiology, vol. 94, no. 2, pp. 151-156, 2004.

[107] V. Randriamboavonjy, F. Pistrosch, B. Bölck et al., "Platelet sarcoplasmic endoplasmic reticulum $\mathrm{Ca}^{2+}$-ATPase and $\mu$-calpain activity are altered in type 2 diabetes mellitus and restored by rosiglitazone," Circulation, vol. 117, no. 1, pp. 52-60, 2008.

[108] M. Kaplar, J. Kappelmayer, A. Veszpremi, K. Szabo, and M. Udvardy, "The possible association of in vivo leukocyte-platelet heterophilic aggregate formation and the development of diabetic angiopathy," Platelets, vol. 12, no. 7, pp. 419-422, 2001.

[109] V. Randriamboavonjy and I. Fleming, "Insulin, Insulin resistance, and platelet signaling in diabetes," Diabetes Care, vol. 32, no. 4, pp. 528-530, 2009.
[110] I. Fleming, C. Schulz, B. Fichtlscherer, B. E. Kemp, B. Fisslthaler, and R. Busse, "AMP-activated protein kinase (AMPK) regulates the insulin-induced activation of the nitric oxide synthase in human platelets," Thrombosis and Haemostasis, vol. 90, no. 5, pp. 863-871, 2003.

[111] V. Randriamboavonjy, J. Schrader, R. Busse, and I. Fleming, "Insulin induces the release of vasodilator compounds from platelets by a nitric oxide-G kinase-VAMP-3-dependent pathway," Journal of Experimental Medicine, vol. 199, no. 3, pp. 347356, 2004.

[112] T. Yamaguchi, K. Kadono, T. Tetsutani, and K. Yasunaga, "Platelet free $\mathrm{Ca}^{2+}$ concentration in non-insulin-dependent diabetes mellitus," Diabetes Research, vol. 18, no. 2, pp. 89-94, 1991.

[113] W. L. Dean, D. Chen, P. C. Brandt, and T. C. Vanaman, "Regulation of platelet plasma membrane $\mathrm{Ca}^{2+}$-ATPase by cAMPdependent and tyrosine phosphorylation," Journal of Biological Chemistry, vol. 272, no. 24, pp. 15113-15119, 1997.

[114] G. Cella, N. Scattolo, C. Vio et al., "Platelet factor 4 (PF4) and heparin released platelet factor 4 (HR-PF4) in diabetes mellitus. Effect of the duration of the disease," Folia Haematologica, vol. 113, no. 5, pp. 646-654, 1986.

[115] S. Sacchi, G. Curci, L. Piccinini et al., "P latelet alpha granule release in diabetes mellitus," Scandinavian Journal of Clinical \& Laboratory Investigation, vol. 45, pp. 165-168, 1985.

[116] V. Henn, S. Steinbach, K. Büchner, P. Presek, and R. A. Kroczek, "The inflammatory action of CD40 ligand (CD154) expressed on activated human platelets is temporally limited by coexpressed CD40," Blood, vol. 98, no. 4, pp. 1047-1054, 2001.

[117] C. Gisinger, J. Jeremy, P. Speiser, D. Mikhailidis, P. Dandona, and G. Schernthaner, "Effect of vitamin E supplementation on platelet thromboxane A2 production in Type I diabetic patients. Double-blind crossover trial," Diabetes, vol. 37, no. 9, pp. 1260 $1264,1988$.

[118] M. Sacco, F. Pellegrini, M. C. Roncaglioni, F. Avanzini, G. Tognoni, and A. Nicolucci, "Primary prevention of cardiovascular events with low dose aspirin and vitamin $\mathrm{E}$ in type 2 diabetic patients: results of the Pimary Prevention Project (PPP) trial," Diabetes Care, vol. 26, no. 12, pp. 3264-3272, 2003.

[119] I. Chung and G. Y. H. Lip, "Platelets and heart failure," European Heart Journal, vol. 27, no. 22, pp. 2623-2631, 2006.

[120] J. Mehta and P. Mehta, "Platelet function studies in heart disease. VI. Enhanced platelet aggregate formation activity in congestive heart failure: inhibition by sodium nitroprusside," Circulation, vol. 60, no. 3, pp. 497-503, 1979.

[121] G. Y. H. Lip, G. D. O. Lowe, M. J. Metcalfe, A. Rumley, and F. G. Dunn, "Effects of warfarin therapy on plasma fibrinogen, von Willebrand factor, and fibrin D-dimer in left ventricular dysfunction secondary to coronary artery disease with and without aneurysms," American Journal of Cardiology, vol. 76, no. 7, pp. 453-458, 1995.

[122] I. Chung, A. Choudhury, and G. Y. H. Lip, "Platelet activation in acute, decompensated congestive heart failure," Thrombosis Research, vol. 120, no. 5, pp. 709-713, 2007.

[123] A. Shah, G. Passacquale, E. Gkaliagkousi, J. Ritter, and A. Ferro, "Platelet nitric oxide signalling in heart failure: role of oxidative stress," Cardiovascular Research, vol. 91, no. 4, pp. 625-631, 2011.

[124] P. Boccardo, G. Remuzzi, and M. Galbusera, "Platelet dysfunction in renal failure," Seminars in Thrombosis and Hemostasis, vol. 30, no. 5, pp. 579-589, 2004. 
[125] D. Kaw and D. Malhotra, "Platelet dysfunction and end-stage renal disease," Seminars in Dialysis, vol. 19, no. 4, pp. 317-322, 2006.

[126] C. Belloc, H. Lu, C. Soria, R. Fridman, Y. Legrand, and S. Menashi, "The effects of platelets on invasiveness and protease production of human mammary tumor cells," International Journal of Cancer, vol. 60, no. 3, pp. 413-417, 1995.

[127] J. M. Lewalle, V. Castronovo, G. Goffinet, and J. M. Foidart, "Malignant cell attachment to endothelium of ex vivo perfused human umbilical vein. Modulation by platelets, plasma and fibronectin," Thrombosis Research, vol. 62, no. 4, pp. 287-298, 1991.

[128] G. C. Haralabopoulos, D. S. Grant, H. K. Kleinman, and M. E. Maragoudakis, "Thrombin promotes endothelial cell alignment in Matrigel in vitro and angiogenesis in vivo," American Journal of Physiology-Cell Physiology, vol. 273, no. 1, pp. C239-C245, 1997.

[129] N. M. Bambace and C. E. Holmes, "The platelet contribution to cancer progression," Journal of Thrombosis and Haemostasis, vol. 9, no. 2, pp. 237-249, 2011.

[130] S. Jain, J. Harris, and J. Ware, "P latelets: linking hemostasis and cancer," Arteriosclerosis, Thrombosis, and Vascular Biology, vol. 30, pp. 2362-2367, 2010.

[131] J. E. Freedman, "Thrombin, thrombomodulin, and extracellular signal-regulated kinases regulating cellular proliferation," Circulation Research, vol. 88, no. 7, pp. 651-653, 2001.

[132] W. Ruf and B. M. Mueller, "Thrombin generation and the pathogenesis of cancer," Seminars in Thrombosis and Hemostasis, vol. 32, supplement 1, pp. 61-68, 2006.

[133] S. Catricala, M. Torti, and G. Ricevuti, "A lzheimer disease and platelets: how's that relevant," Immunity \& Ageing, vol. 9, p. 20, 2012.

[134] C. Iarlori, D. Gambi, F. Gambi et al., "Expression and production of two selected beta-chemokines in peripheral blood mononuclear cells from patients with Alzheimer's disease," Experimental Gerontology, vol. 40, no. 7, pp. 605-611, 2005.

[135] G. S. Zubenko, B. M. Cohen, C. F. Reynolds III, F. Boller, I. Malinakova, and N. Keefe, "Platelet membrane fluidity in Alzheimer's disease and major depression," American Journal of Psychiatry, vol. 144, no. 7, pp. 860-868, 1987.

[136] C. I. Prodan, E. D. Ross, J. A. Stoner, L. D. Cowan, A. S. Vincent, and G. L. Dale, "Coated-platelet levels and progression from mild cognitive impairment to Alzheimer disease," Neurology, vol. 76, no. 3, pp. 247-252, 2011.

[137] L. Amitrano, M. A. Guardascione, V. Brancaccio, and A. Balzano, "Coagulation disorders in liver disease," Seminars in Liver Disease, vol. 22, no. 1, pp. 83-96, 2002.

[138] E. F. Mammen, "Coagulation abnormalities in liver disease," Hematology/Oncology Clinics of North America, vol. 6, no. 6, pp. 1247-1258, 1992.

[139] P. A. McCormick and K. M. Murphy, "Splenomegaly, hypersplenism and coagulation abnormalities in liver disease," Best Practice and Research, vol. 14, no. 6, pp. 1009-1031, 2000.

[140] G. G. C. Hugenholtz, R. J. Porte, and T. Lisman, “The platelet and platelet function testing in liver disease," Clinics in Liver Disease, vol. 13, no. 1, pp. 11-20, 2009.

[141] T. Maruyama, S. Murata, K. Takahashi et al., "Platelet transfusion improves liver function in patients with chronic liver disease and cirrhosis," The Tohoku Journal of Experimental Medicine, vol. 229, pp. 213-220, 2013.
[142] A. Panasiuk, D. Prokopowicz, J. Zak, J. Matowicka-Karna, J. Osada, and J. Wysocka, "Activation of blood platelets in chronic hepatitis and liver cirrhosis P-selectin expression on blood platelets and secretory activity of $\beta$-thromboglobulin and platelet factor-4," Hepato-Gastroenterology, vol. 48, no. 39, pp. 818-822, 2001. 


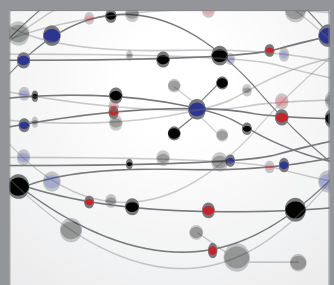

The Scientific World Journal
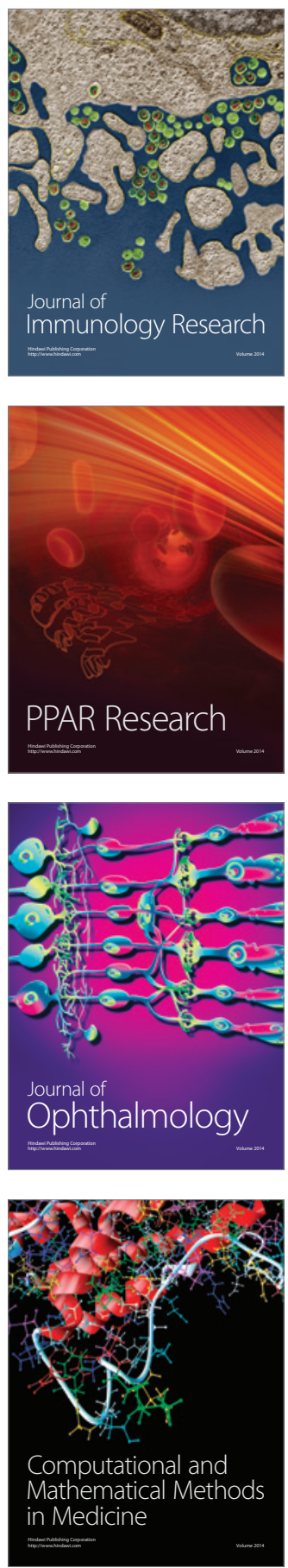

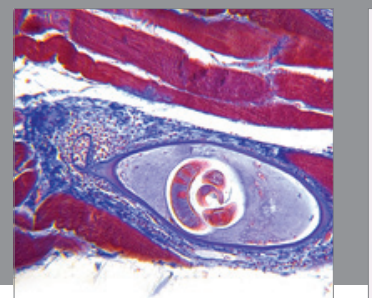

Gastroenterology

Research and Practice
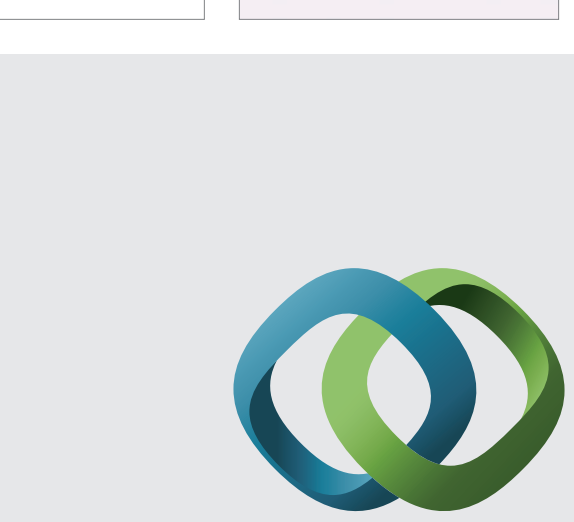

\section{Hindawi}

Submit your manuscripts at

http://www.hindawi.com
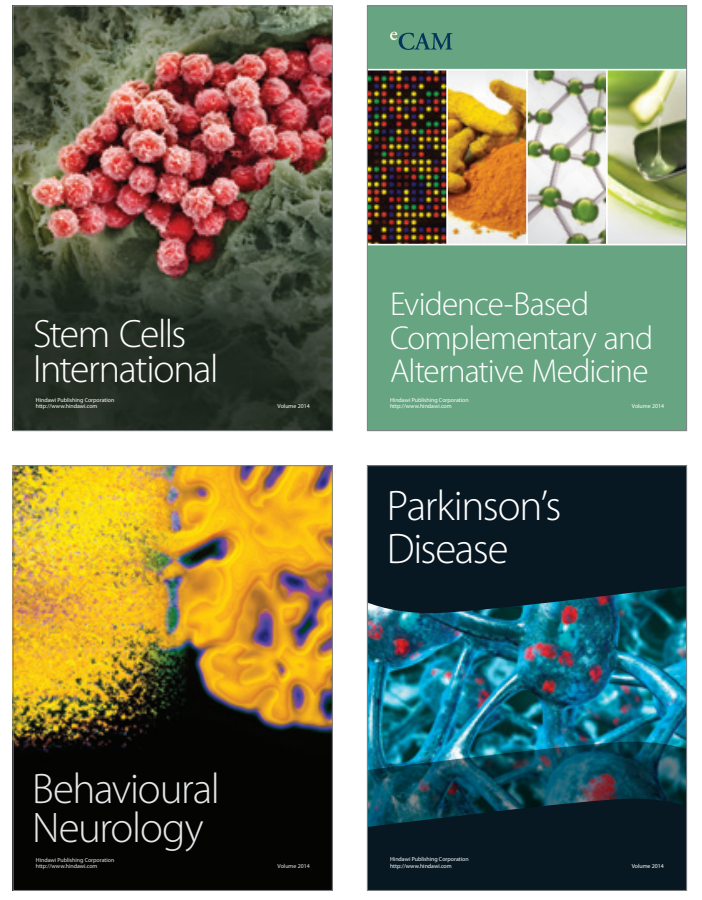
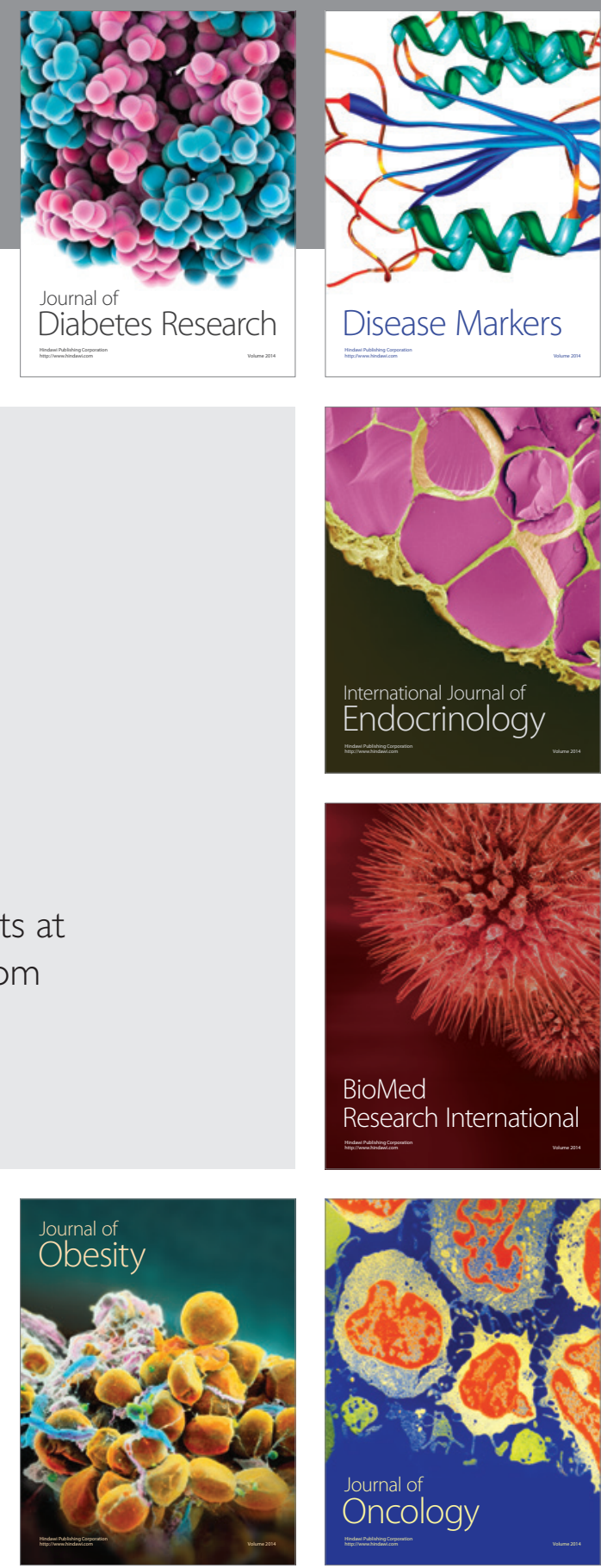

Disease Markers
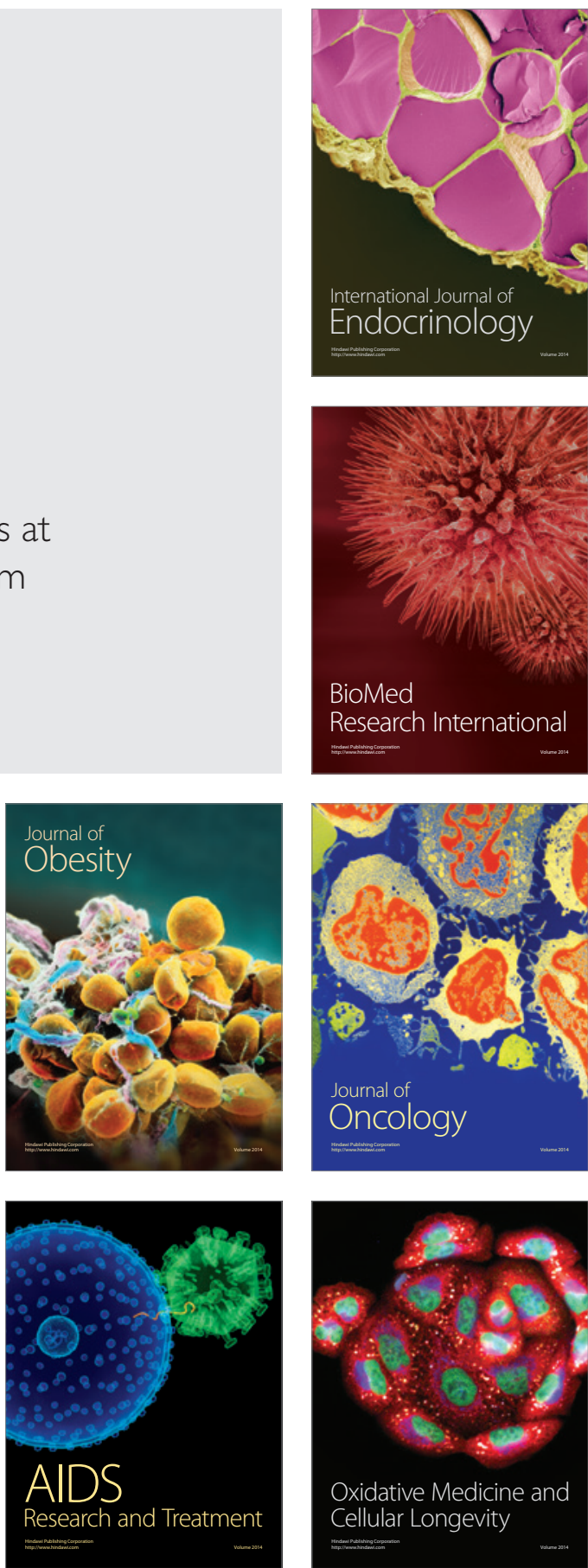